
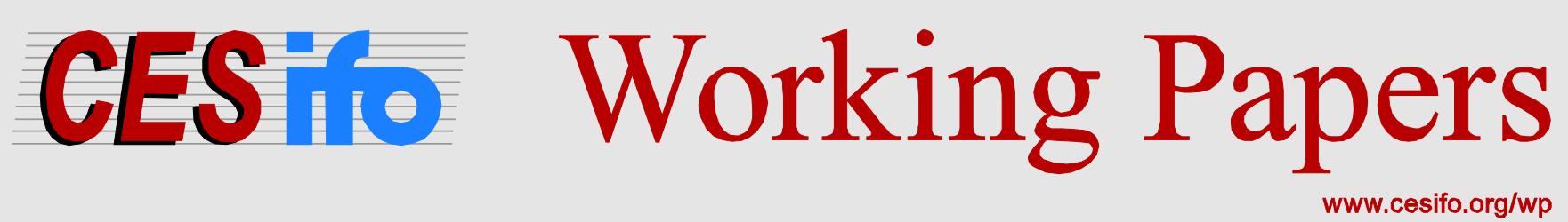

\title{
Fiscal Transfers and Fiscal Sustainability
}

\author{
Niklas Potrafke \\ Markus Reischmann
}

CESIFO WORKING PAPER NO. 4716

CATEGORY 1: PuBliC FinANCE

MARCH 2014

An electronic version of the paper may be downloaded

- from the SSRN website:

- from the RePEc website:

- from the CESifo website:

WWW.SSRN.com

www.RePEc.org

www.CESifo-group.org/wp

\section{CESifo}




\title{
Fiscal Transfers and Fiscal Sustainability
}

\begin{abstract}
We examine whether US and German state governments pursue sustainable fiscal policies taking into account fiscal transfers. Using panel data techniques we investigate whether the debt-to-GDP ratio had a positive influence on the primary surplus (Bohn-model). We show that including/excluding fiscal transfers changes the results. If fiscal transfers are not included in the primary surplus, the test results do not indicate that the US and German state governments pursued sustainable fiscal policies. Our results also suggest that fiscal transfers were positively related with debt. These findings indicate that intergovernmental transfers have implicitly subsidized debts.
\end{abstract}

JEL-Code: H720, H740, H770, C230.

Keywords: fiscal sustainability, public debt, institutions, fiscal transfers, panel data.

Niklas Potrafke

Ifo Institute - Leibniz Institute for

Economic Research

at the University of Munich

Poschingerstr. 5

Germany - 81679 Munich

potrafke@ifo.de
Markus Reischmann

Ifo Institute - Leibniz Institute for

Economic Research

at the University of Munich

Poschingerstr. 5

Germany-81679 Munich

reischmann@ifo.de

This paper has been accepted for publication in the Journal of Money, Credit and Banking. 


\section{INTRODUCTION}

A most topical question in Public Finance is whether governments pursue sustainable fiscal policies. When fiscal policy is shown to be unsustainable, policies should be changed. Governments may, for example, cut spending, increase public revenues, or implement nonbudgetary policies that promote economic growth. Empirical tests of fiscal sustainability are also important because they can be used to publicize the government's fiscal policy performance which may thereby influence the government's (re-)election prospects.

The purpose of this paper is to show that the institutional setting of fiscal policy making needs to be considered in fiscal sustainability tests. In federal states such as the United States and Germany, fiscal transfers between jurisdictions influence the budgets of the federal and lower tier governments. Paying fiscal transfers impairs of course a government's fiscal performance, whereas receiving fiscal transfers appears to improve it. It is therefore possible that ignoring fiscal transfer payments in empirical tests of fiscal sustainability gives rise to misleading conclusions. In particular, when a government with a dismal fiscal performance receives a transfer, empirical tests may predict that the government's fiscal policy is sustainable because of the transfer but not because of the government's sound fiscal policy. By using data for the US states and the German states (Laender), we show that including fiscal transfers in the state budgets influences the inferences regarding fiscal sustainability.

Debt sustainability in federal states is an important issue because a lack of fiscal coordination has been implicated in many debt crises, such as currently in the Eurozone (if interpreted as an emerging federal system), and historically (e.g., Argentina before 2001). In the light of the European debt crisis a deeper fiscal integration in the Eurozone is widely discussed. Many experts have argued that a currency union should be accompanied by a fiscal union (see, e.g., Kenen 1969, Sala-i-Martin and Sachs 1992, Masson 1996). A fiscal transfer system may stabilize country-specific economic shocks and mitigate the accumulation of debt in individual Euro member states. The United States and Germany are good laboratories to study debt sustainability and fiscal coordination because they have well established federal systems and detailed data is available.

A very prominent test for fiscal sustainability is to examine whether the debt-to-GDP ratio in period $\mathrm{t}-1$ has a positive influence on the primary surplus-to-GDP ratio in period $\mathrm{t}$ using a fiscal reaction function (Bohn-model: Bohn 1998, 2008). Governments pursue sustainable fiscal policies when the debt-to-GDP ratio in period t-1 has a positive influence on the primary surplus in period t. An increase in the primary surplus means that the government takes corrective measures by increasing revenues and/or cutting expenditures to counteract the accumulation of public debt. We apply the Bohn-model in a panel of US and German state governments. ${ }^{3}$ We provide evidence that fiscal transfers are critical for fiscal sustainability in the states. Our findings also indicate that fiscal transfers have implicitly subsidized debts in the states.

\footnotetext{
${ }^{3}$ Scholars also use unit root tests to examine whether the debt-to-GDP ratio has a unit root and investigate whether public revenues and public expenditures are cointegrated to analyze fiscal sustainability. Bohn (2007) shows that the intertemporal budget constraint, and therefore fiscal sustainability, may be satisfied even if the debt series contains a unit root and even if revenues and expenditures are not cointegrated. The critical values of panel unit root and cointegration tests for bounded variables such as debt-to-GDP ratios also need to be adjusted (Herwartz and Xu 2008, Cavaliere and Xu 2014).
} 


\section{PRIOR STUDIES AND RESEARCH FRAMEWORK}

Several studies have examined fiscal sustainability on the national level. ${ }^{4}$ Fiscal sustainability tests are applied by using univariate time series techniques and panel data techniques. Bohn (1998) and Bohn (2008) examine the sustainability of fiscal policy of the US federal government using univariate time series over the period 1916-1995 and 1793-2003, and find a positive response of the primary surplus to changes in public debt. Mendoza and Ostry (2008) test the Bohn-model in a panel of 22 industrial countries over the period 1980-2005 and in a panel of 34 emerging countries over the period 1990-2005. In both groups they find a positive response of the primary surplus to changes in public debt. By distinguishing between high-debt and low-debt countries, Mendoza and Ostry show that countries with moderate debt levels pursued sustainable fiscal policies and countries with debt-to-GDP ratios above the sample mean and median of each group did not pursue sustainable fiscal policies. Ghosh et al. (2013) find a cubic reaction function of the primary surplus to public debt in a panel of 23 advanced economies over the period 1970-2007. At low debt levels, debt had no, or even a negative influence on the primary surplus, but when debt rose beyond a certain threshold, the influence of debt on the primary surplus became positive and increased. Very high debt levels had even a negative influence on the primary surplus. Ghosh et al. emphasize that governments could no longer service public debt at very high levels of debt because "fiscal fatigue" began. "Fiscal fatigue" means that governments are not able any more to increase the primary surplus to counteract the accumulation of public debt at very high debt levels.

Claeys, Ramos, and Suriňach (2008) estimate the Bohn-model in a panel of the US states over the period 1962-2000, and a panel of the German states over the period 19702005. The results show that the US state governments pursued sustainable fiscal policies, while the German state governments did not. Fincke and Greiner (2011) use univariate time series for the West German states over the period 1975-2006 and show that the debt-to-GDP ratio had a positive influence on the primary surplus in all the West German states except Berlin. In a similar vein, Kitterer (2007) and Kitterer and Finken (2006) use univariate time series for the West German states over the period 1971-2004 and for the East German states over the period 1992-2004 and show with the help of univariate unit root tests that only governments in Hesse, North-Rhine Westphalia, and Saxony pursued sustainable fiscal policies. Herzog (2010) tests the Bohn-model for Baden-Wuerttemberg and Berlin over the period 1970-2005. The results show that fiscal policy was sustainable in BadenWuerttemberg and not sustainable in Berlin.

We investigate whether the debt-to-GDP ratio in period t-1 had a positive influence on the primary surplus-to-GDP ratio in period t using a fiscal reaction function (Bohn-model). We estimate panel models for the US and German state governments which include fixed state and fixed period effects. We also estimate dynamic panel models because governments may change public revenues and expenditures gradually to adjust the primary surplus to debt. We examine whether public debt had a non-linear influence on the primary surplus.

Proponents of the "fiscal theory of the price level" criticize that the fiscal reaction function might not measure a causal influence of the debt level on the primary surplus because the debt-to-GDP ratio might react to expected primary surpluses (Canzoneri, Cumby, and Diba 2001, Woodford 1998). The primary surplus in period t should, however, by

\footnotetext{
${ }^{4}$ See, e.g., Hamilton and Flavin (1986), Trehan and Walsh (1988, 1991), Wilcox (1989), Quintos (1995), Ahmed and Rogers (1995), Fincke and Greiner (2012), Koester and Priesmeier (2013), Byrne, Fiess, and MacDonald (2011), Prohl and Westerlund (2009), Burret, Feld, and Köhler (2013). On theoretical considerations of public debt sustainability, see Bohn (1995, 2007, 2008).
} 
definition not have an influence on debt in period t-1 because of the time lag. In any event, we employ a two-step system GMM estimator to deal with the potential reverse causality between the debt level and the primary surplus.

We explicitly take into account fiscal transfers when assessing fiscal sustainability. Our study is closely related to Mahdavi and Westerlund (2011) who employ panel unit root and cointegration tests to investigate fiscal policies of US state and local governments. Mahdavi and Westerlund explore as to what extent balanced budget rules facilitate fiscal sustainability and arrive at the result that without federal grants, state and local governments as a group are unable to fund their current operation expenditures using their own-source revenues. (Mahdavi and Westerlund 2011, p. 963)

\section{INSTITUTIONAL BACKGROUND IN THE UNITED STATES AND GERMANY}

\subsection{Fiscal transfer systems}

A typical feature of fiscal federalism in the United States and Germany are fiscal transfer systems which fund the budgets of the lower tier state governments. The institutional design of fiscal federalism, however, differs between the United States and Germany. In the United States the states receive transfers (grants) from the federal level (vertical), while in Germany the transfer payments flow from the federal level to the states (vertical) and between the states (horizontal). The intergovernmental transfers in the United States mostly depend on spending in the states, while the intergovernmental transfers in Germany depend on tax revenues in the states.

The US states receive three types of grants, depending on how much discretionary power the recipient has on using the funds: categorical grants for specific activities, block grants for a wider range of activities, and general purpose grants (GAO 2012). The individual grants are either based on pre-determined formulas (formula grants) or designed for statespecific projects (project grants). Formula grants allocate funds based on indicators such as population and per capita income. The states can apply for project grants which allocate funds on a competitive basis (GAO 2009). By paying grants the US federal government reimburses the states for the performance of general government functions (e.g., health, education, public transport, and unemployment compensation) and specific services (e.g., care of prisoners), or in lieu of taxes on federal property. The fiscal transfer system in the United States is de jure not intended to equalize fiscal imbalances among the states. Sørensen, Wu, and Yosha (2001) describe, however, that federal grants react countercyclically with respect to state-level output fluctuations and provide some insurance against state-specific downturns. By comparing fiscal policies in Florida and Spain, Krugman (2012) describes how fiscal transfers have de facto stabilized budgets in Florida and proposes to also introduce fiscal transfers between European countries. Both, Florida and Spain, had large housing bubbles which burst in 2007. While Spain has to counteract the subsequent increase in public debt with austerity measures, Florida receives a large financial support from the federal level via transfers. If Florida suffers an asymmetric adverse shock, it will receive an automatic compensating transfer from the rest of the country: it pays less into the national budget, but this has no impact on the benefits it receives, and may even increase its benefits if they come from programs like unemployment benefits, food stamps, and Medicaid that expand in the face of economic distress. (Krugman 2012, p. 5) 
The German fiscal equalization system harmonizes tax revenues across the states. The horizontal transfers redistribute tax revenues from rich states to poor states. States with above average per capita tax revenues pay transfers, while states with below average per capita tax revenues receive transfers. The vertical transfers are additional grants from the federal government to states with low per capita tax revenues. Until 2005 vertical and horizontal transfers adjusted the poor states' income effectively to $99.5 \%$ of average tax revenues per capita (Baretti, Huber, and Lichtblau 2002). After a reform of the fiscal equalization scheme in 2005 poor states receive at least $97.5 \%$ of average tax revenues per capita (Bundesministerium der Finanzen 2012). Since 1995, the East German states have participated in the system (received transfers), and the volume of payments has increased. In fact, some states are permanent net recipients while others are permanent net payers of transfers. In 1988 the German states Bremen and Saarland went to the Supreme Court to demand additional transfers from the federal government. Bremen and Saarland had accumulated high public debts. The Supreme Court arrived at the conclusion that the two states were unable to reduce their debts by own means. Between 1994 and 2004 the federal government paid additional vertical transfers to reduce debt in Bremen and Saarland (Seitz 2000).

\subsection{Fiscal policy on the state level}

The US states have discretionary power in setting tax bases and rates. The US state governments decide upon most major expenditures with only a few exceptions such as pensions and health insurance for old and disabled people (Bordo, Jonung, and Markiewicz 2013). ${ }^{5}$ The states are generally free in borrowing but need to fulfill balanced-budget-rules (Vermont is an exception). The requirements of the balanced-budget-rules are, however, not equally stringent across the states. Some balanced budget requirements provide enough flexibility for states to carry over deficits if necessary. (GAO 1993, p. 40) Poterba (1996) describes that almost every US state has the possibility to borrow to balance the budget at least for one fiscal year and that most balanced budget rules cover only a part of the overall budget. ${ }^{6}$ Most states do not have formal provisions to enforce the balanced budget rules.

In Germany, federal law determines nearly all tax bases and rates. The state governments have hardly any means to change tax rates. The state governments can, however, influence tax revenues implicitly by, for example, boosting economic performance or increasing tax enforcement activities. The revenues of the VAT, the income tax, and the corporate tax are shared among the federal, state and local governments. The German state governments are restrained by federal law on the expenditure side. The German states have, however, full autonomy in borrowing. Until 2009 the constitutional and statutory provisions of the states allowed borrowing only in the amount of expenditures for investments ("golden rule"). But the state governments found various ways to circumvent or simply ignored the "golden rule" (Rodden 2003). In 2009 the German federal government introduced a new debt break prohibiting the states to run structural deficits from 2020 onwards.

\footnotetext{
${ }^{5}$ The states typically have very limited discretion over the net revenue flow to social insurance funds. (Poterba 1994, p. 800) Consequently, we consider general revenues and general expenditures of the US states which do not include revenues and expenditures of utilities, liquor stores, and insurance trusts.

${ }^{6}$ See also Heun (2014).
} 


\section{DATA AND DESCRIPTIVE ANALYSIS}

\subsection{Public debt and the primary surplus in the US and German states}

For the US states we use annual data over the period 1978-2010. ${ }^{7}$ For the German states we use annual data over the period $1975-2010 .{ }^{8}$ Tables $1 \mathrm{a}$ and $1 \mathrm{~b}$ describe the data sources.

In our baseline specification we use data on the state government level, excluding municipalities. We exclude the municipalities because we want to explicitly investigate fiscal policies of the state governments and analyze how fiscal transfers influence fiscal policy on the state level. We also discuss results including municipalities in the robustness tests section.

We exclude outliers from our samples. Alaska and Wyoming play a special role among the US states because they have extraordinarily large surpluses because of their high revenues coming from taxes on oil. Hawaii has a unique full-state responsibility for public education among the US states. We thus exclude Alaska, Hawaii, and Wyoming from our panel of the US states (see Bohn and Inman 1996). The city state Berlin plays a special role among the German states. Before 1990, West Berlin was part of the Federal Republic of Germany. In 1990, West and East Berlin were unified and the fiscal data for Berlin thus has a structural break. Data on fiscal transfers to the East German states is only available after 1995 and their debt-to-GDP ratios rose dramatically after the German reunification. We thus only consider the West German states excluding Berlin.

The average debt-to-GDP ratio of the US state governments in our sample is $6.4 \%$. The average debt-to-GDP ratio of the West German state governments is $19.0 \%$.

We propose two alternatives to measure the primary surplus. First, we use the standard definition of the primary surplus: the difference between revenues and primary expenditures (primary surplus 1). Primary expenditures are all expenditures, excluding interest payments. Second, we exclude transfers paid and received by the fiscal transfer system from the primary surplus (primary surplus 2). ${ }^{9}$ The official revenue and expenditure data include the transfers by the fiscal transfer systems. The state governments cannot, however, directly influence these transfers.

Figures 1a and 1b show the annual primary surplus-to-GDP ratios in the US and West German states. The figures illustrate that the federal transfers in the United States balanced the revenues and primary expenditures of the states while many states would have run large primary deficits without transfers. In West Germany the vertical and horizontal transfers also balanced the revenues and primary surpluses of the states in most periods. In the US states the average primary surplus 1-to-GDP ratio was $0.5 \%$ and the average primary surplus 2-toGDP ratio was $-2.4 \%$ over the period 1978-2010. In the West German states, the average primary surplus 1-to-GDP ratio over the period 1975-2010 was $0,0 \%$ and the average primary surplus 2-to-GDP ratio was $-0.6 \%$.

\footnotetext{
${ }^{7}$ Data on real GDP in the US states is available only since 1977 and we use the GDP deflator to compute real values. In a some of our regressions we include lagged real income and consequently our first year in the sample is 1978 (see Sørensen, Wu, and Yosha 2001, Larcinese, Rizzo, and Testa 2013 who also use data starting in 1978).

${ }^{8}$ Data on revenues and expenditures in the German states is available since 1974. Because we include lagged variables, our first year in the sample is 1975 .

${ }^{9}$ For the US states we use net federal grants, calculated as intergovernmental revenues of the state from the federal government minus intergovernmental expenditures of the state to the federal government (see Sørensen, Wu, and Yosha 2001).
} 


\subsection{Correlation between public debt and the primary surplus}

Figures $2 \mathrm{a}$ and $2 \mathrm{~b}$ show correlations between the two measures of the primary surplus-toGDP ratio in period $t$ and the debt-to-GDP ratio in period $t-1$ of the US and German state governments. Public debt was positively correlated with the standard measure of the primary surplus (primary surplus 1) in the US states as well as in the West German states. The correlation coefficient between the debt-to-GDP ratio in period t- 1 and the primary surplusto-GDP ratio in period $t$ is 0.42 in the US states and 0.23 in the West German states. By contrast, when excluding the fiscal transfers (primary surplus 2), the debt-to-GDP ratio was negatively correlated with the primary surplus-to-GDP ratio: the correlation coefficient between the debt-to-GDP ratio in period $\mathrm{t}-1$ and the primary surplus-to-GDP ratio in period $\mathrm{t}$ is -0.05 in the US states and -0.53 in the West German states. The correlations do, however, not take into account the development over time, individual state effects and other covariates, which we consider in the econometric panel data model.

\section{ECONOMETRIC ANALYSIS}

\subsection{Empirical specification}

The baseline panel data model has the following form:

$$
\text { 'Primary Surplus' }{ }_{\mathrm{ijt}}=\alpha_{\mathrm{j}} \text { 'Public Debt' }{ }_{\mathrm{it}-1}+\sum_{\mathrm{l}} \beta_{\mathrm{jl}} \mathrm{Z}_{\mathrm{it}}+\eta_{\mathrm{i}}+\varepsilon_{\mathrm{t}}+\mathrm{u}_{\mathrm{ijt}}
$$

where the dependent variable 'Primary Surplus' ${ }_{\mathrm{ijt}}$ denotes the primary surplus-to-GDP ratio in state $\mathrm{i}$ in period $\mathrm{t}$. We distinguish between two measures of the primary surplus denoted by $\mathrm{j}$. The first measure is the standard definition of the primary surplus (primary surplus 1 ), the second measure excludes fiscal transfers (primary surplus 2). 'Public Debt' ${ }_{\text {it-1 }}$ describes the debt-to-GDP ratio in period $t-1$. The vector $Z_{i t}$ includes two variables that control for business cycle fluctuations and temporary government spending. We choose the control variables following Barro's (1979) tax smoothing theory which implies that the determinants of the primary surplus other than debt are a business cycle indicator, YVAR, and the level of temporary government spending, GVAR. Barro (1986) defines YVAR $=\left(1-\mathrm{y}_{\mathrm{t}} / \mathrm{y}_{\mathrm{tT}}\right) *\left(\mathrm{~g}_{\mathrm{tT}} /\right.$ $\left.\mathrm{y}_{\mathrm{t}}\right)$ and GVAR $=\left(\mathrm{g}_{\mathrm{t}}-\mathrm{g}_{\mathrm{tT}}\right) / \mathrm{y}_{\mathrm{t}}$, where $\mathrm{y}_{\mathrm{t}}$ and $\mathrm{g}_{\mathrm{t}}$ describe the actual values of real GDP and real expenditures, ${ }^{10}$ and $\mathrm{y}_{\mathrm{tT}}$ and $\mathrm{g}_{\mathrm{tT}}$ the trend values of $\mathrm{y}_{\mathrm{t}}$ and $\mathrm{g}_{\mathrm{t} .}{ }^{11}$ YVAR measures the relative deviation of actual output to trend output weighted by $\left(\mathrm{g}_{\mathrm{t}} / \mathrm{y}_{\mathrm{t}}\right)$. Positive values of YVAR indicate an actual output below the trend (output shortfall). GVAR measures the amount of temporary spending above trend spending. A positive value of GVAR indicates actual expenditures above the trend. Alternatively, Bohn (2008) uses the difference between the actual value and trend value of log real GDP as a proxy for the output gap and the difference between actual and estimated permanent military outlays (relative to GDP) as a proxy for the expenditure gap. In contrast to Barro's approach, a positive output gap in Bohn's approach indicates an output above the trend (output surplus). We use all government expenditures excluding interest payments to compute GVAR and the expenditure gap variable (see

\footnotetext{
${ }^{10}$ We calculate the real values using the GDP deflator of every individual state.

${ }^{11}$ We calculate the trend values by using the Hodrick-Prescott filter using a smoothing parameter of 100.
} 
Mendoza and Ostry 2008, Ghosh et al. 2013). ${ }^{12}$ We expect YVAR, GVAR, and the expenditure gap variable to have a negative influence on the primary surplus, and the output gap variable to have a positive influence on the primary surplus. If output is below its trend, the primary surplus should decrease. Similarly, if government spending is above its trend, the primary surplus should decrease. $\eta_{i}$ describes a fixed state effect, $\varepsilon_{t}$ describes a fixed period effect and $\mathrm{u}_{\mathrm{ijt}}$ describes an error term.

We discuss results including and excluding YVAR and GVAR (or the output gap and expenditure gap variables) for two important reasons. First, defining the expenditure gap variables has been a major issue in related studies. Bohn (1998) uses, for example, univariate data for the United States including the period of the World Wars and needs to account for these extraordinary periods by designing the expenditure gap variable. We include, however, fixed period effects in our panel data model addressing external shocks. Second, we acknowledge that our definition using overall expenditures to compute the expenditure gap variable may give rise to endogeneity concerns. We thus show that including/excluding the output gap and expenditure gap variables does not change the inferences.

We estimate the baseline model by using OLS with standard errors robust to heteroskedasticity (Huber/White/sandwich standard errors - see Huber 1967, White 1980 and 1982, and Stock and Watson 2008).

Governments may change public revenues and expenditures gradually to adjust the primary surplus to debt (see, e.g., Blanchard 1984). The results excluding the lagged dependent variable may suffer from omitted variable bias. We thus also estimate dynamic panel data models including the lagged dependent variable.

We consider the potential endogeneity of debt because expectations of tomorrow's primary surplus can influence today's debt. Experts have not yet find a suitable external instrument for debt. We thus have to draw instruments from within our panel and instrument debt by its time lags as suggested by Checherita-Westphal and Rother (2012). ${ }^{13}$ We estimate the model by using the two-step system GMM estimator as developed by Arellano and Bover (1995) and Blundell and Bond (1998) and employ the two-step estimator implemented by David Roodman in Stata, including Windmeijer's (2005) finite sample correction. We collapse the instruments and limit the number of lags as suggested by Roodman (2006, 2009). ${ }^{14}$

Tables 2a and 2b show descriptive statistics for all variables.

\subsection{Results}

\subsubsection{Fiscal reaction functions}

Tables 3a and 3b show the regression results for the US state governments when the standard definition of the primary surplus-to-GDP ratio (primary surplus 1) is used. Table 3a shows

\footnotetext{
${ }^{12}$ When the primary surplus 2 is used as dependent variable, we use YVAR, GVAR, and expenditure gap variables that exclude fiscal transfer expenditures. Inferences do not change when we use YVAR, GVAR, and expenditure gap variables that include fiscal transfer expenditures.

${ }^{13}$ See Bazzi and Clemens (2013) on internal instruments and the exclusion restrictions.

${ }^{14}$ We follow Checherita-Westphal and Rother (2012) who instrument debt through its time lags up to the 5th lag. Inferences regarding the lagged debt-to-GDP ratio do not change and the diagnostic statistics of the GMM estimator show that the model is well specified up to a maximum of 9 lags.
} 
the results of the OLS regressions. In column (1) we only include fixed state and period effects, in column (2) we include the control variables YVAR and GVAR, and in column (3) we include the control variables output gap and expenditure gap. The results show a positive influence of the debt-to-GDP ratio in period t-1 on the primary surplus-to-GDP ratio in period t. The coefficient of the debt-to-GDP ratio in period t- 1 is statistically significant at the $1 \%$ level. Our result indicates that the primary surplus-to-GDP ratio in period t increased by about 0.05 percentage points when the debt-to-GDP ratio in period t- 1 increased by one percentage point. ${ }^{15}$ In the columns (4) to (6) we include the lagged dependent variable. The coefficient of the lagged debt-to-GDP ratio decreases to 0.03 and is statistically significant at the $1 \%$-level.

The YVAR variable (output shortfall) has the expected negative sign and is statistically significant at the $1 \%$-level in column (2) and at the $5 \%$ level in column (5). The output gap variable (output surplus) has the expected positive sign and is statistically significant at the 1\%-level in column (2) and at the 5\% level in column (5). If output was below its trend, the primary surplus decreased. The GVAR variable and the expenditure gap variable (temporary government spending) are significant at the 1\%-level and have the expected negative sign. If government spending was above its trend, the primary surplus decreased.

Including the lagged dependent variable in our fixed effects regressions gives rise to Nickell bias (Nickell 1981). The coefficients might be biased by $1 / T$, i.e. $3 \%$. We thus also employ dynamic two-step system GMM estimations. Table 3b shows the result of the GMM estimations for the US state governments using the primary surplus 1 . In columns (1) to (3) we treat the lagged primary surplus 1-to-GDP ratio as endogenous. The coefficient of the lagged debt-to-GDP ratio is about 0.04 and is statistically significant at the $1 \%$-level. In columns (4) to (6) we treat the lagged primary surplus 1-to-GDP ratio and the lagged debt-toGDP ratio as endogenous. The coefficient of the lagged debt-to-GDP ratio is statistically significant at the $1 \%$-level.

Using the standard measure of the primary surplus gives rise to the conclusion that US state governments pursued sustainable fiscal policies. Inferences regarding the debt-to-GDP ratio in period t-1 do not change when we include/exclude the output gap and expenditure gap variables.

To evaluate the US states' discretionary fiscal policy we exclude federal transfers to the states from the revenue side (primary surplus 2). Table 4a shows the results of the OLS regressions for the US state governments when we use the primary surplus 2 . The coefficient of the debt-to-GDP ratio in $\mathrm{t}-1$ does not have a statistically significant influence on the primary surplus 2 in period t. The results contrast with the results when the primary surplus includes federal grants.

The YVAR, GVAR, and expenditure gap variables are statistically significant at the $1 \%$-level and have the expected negative sign and the output gap variable is statistically significant at the $1 \%$-level and has the expected positive sign. ${ }^{16}$ Compared to the estimation

\footnotetext{
${ }^{15}$ Bohn (1998) finds a coefficient of the debt-to-GDP ratio for the US federal government of about 0.054 for the period 1916-1995. Bohn (2008) finds a coefficient between 0.094 and 0.121 for the period 1792-2003. Mendoza and Ostry (2008) find a coefficient of the debt-to-GDP ratio in a panel of 22 industrial countries over the period 1980-2005 between 0.020 and 0.038 and in a panel of 34 emerging countries over the period 1980-2005 between 0.035 and 0.107 .

${ }^{16}$ The GVAR and expenditure gap variables have coefficients near (-1). Given that the primary surplus equals revenues minus primary expenditures, it is conceivable that the regressors essentially cancel out the spending
} 
including federal grants the estimated coefficients of the YVAR and output gap variables are larger. Our finding is in line with Sørensen, Wu, and Yosha (2001) who describe that federal grants are countercyclical with respect to state-level output fluctuations and provide some insurance against state-specific downturns.

Table 4b shows the result of the dynamic two-step system GMM estimations for the US state governments using the primary surplus 2 . The coefficient of the lagged debt-to-GDP ratio lacks statistical significance in all specifications. Inferences thus do not change when we treat the lagged debt-to-GDP ratio as endogenous. Without federal grants the results do not show that governments in the US states have pursued sustainable fiscal policies.

Table 5 shows the results for the German state governments when the standard definition of the primary-surplus-to-GDP ratio is used (primary surplus 1). The results show a positive influence of the debt-to-GDP ratio in period t-1 on the primary surplus-to-GDP ratio in period t. In columns (1) to (3) the coefficient of the debt-to-GDP ratio in t-1 takes values between 0.07 and 0.08 and is statistically significant at the $1 \%$-level. Our result indicates that the primary surplus-to-GDP ratio in period t increased by between 0.07 and 0.08 percentage points when the debt-to-GDP ratio in period t-1 increased by one percentage point. In the columns (4) to (6) we include the lagged dependent variable. The estimated coefficient of the lagged debt-to-GDP ratio decreases to values between 0.03 and 0.04 and is significant at the $1 \%$-level in columns (4) and (6) and at the 5\% level in column (5). We have also estimated dynamic GMM models for the German states treating the lagged primary surplus-to-GDP ratio and the lagged debt-to-GDP ratio as endogenous. Because of the small number of German states the diagnostic statistics perform poorly in the GMM models (see Roodman 2006, 2009). We thus cannot estimate well-specified GMM models for the German states. Using the standard measure of the primary surplus gives rise to the conclusion that West German state governments pursued sustainable fiscal policies.

The YVAR and output gap variables do not turn out to be statistically significant at conventional levels. The design of the German fiscal equalization scheme may well explain why the YVAR and output gap variables do not have a statistically significant influence on the primary surplus. Periods of output shortfalls in a state are associated with decreasing tax revenues. When the tax revenues decrease in a transfer paying state its transfer payment obligation decreases. When the tax revenues decrease in a transfer receiving state, the transfers received increase. The German fiscal equalization scheme thus provides insurance against decreasing tax revenues to the states. The GVAR and expenditure gap variables are statistically significant at the 1\%-level and have the expected negative sign. If government spending is above its trend, the primary surplus decreases.

To evaluate the German states' discretionary fiscal policy we exclude vertical and horizontal transfers via the fiscal equalization scheme from the primary surplus (primary surplus 2). Table 6 shows the results for the West German state governments when we use the primary surplus 2. The coefficient of the debt-to-GDP ratio in t-1 does not have a statistically significant influence on the primary surplus 2 in period t. The results contrast with the results when the primary surplus includes fiscal equalization transfers.

Using the primary surplus 2 as dependent variable, the YVAR variable has the expected negative sign and is statistically significant at the 10\%-level (column 2). The output

side of the primary surplus and the regressions reduce to explaining revenue responses. As a robustness check we have employed regressions without the GVAR and expenditure gap variables. Inferences do not change when the GVAR and expenditure gap variables are excluded. 
gap variable has the expected positive sign but does not turn out to be statistically significant at conventional levels. The GVAR and the expenditure gap variables are statistically significant at the $1 \%$-level and have the expected negative sign. Inferences do not change when we include the lagged dependent variable. The output gap variable, however, turns out to be statistically significant at the $10 \%$-level when we include the lagged dependent variable and has the expected positive sign (column 6). Adjusting the primary balances of the states for fiscal transfers we do not find that governments in the West German states have pursued sustainable fiscal policies.

\subsubsection{Have fiscal transfers subsidized debts in the states?}

Our findings indicate that intergovernmental transfers in the United States and Germany have implicitly subsidized debts in the states. To be sure, federal transfers are not explicitly contingent on state debts, neither in the United States nor in Germany. Taking difference across our otherwise identical regressions including and excluding transfers, one may infer that transfers depend positively on the lagged debt-to-GDP ratio.

Figure 3a shows the correlations between the transfers-to-GDP ratio in period $t$ and the lagged debt-to-GDP ratio in period t-1 in the US states. The correlation coefficient between the transfers-to-GDP ratios and the lagged debt-to-GDP ratio is 0.30 . Figure $3 \mathrm{~b}$ shows the correlations between the transfers-to-GDP ratio in period $t$ and the debt-to-GDP ratio in period t-1 in the West German states. The correlation coefficient between the transfers-to-GDP ratio and the lagged debt-to-GDP ratio is 0.67 .

We have run regressions of the transfer-to-GDP ratio (the difference between primary surplus 1 and 2) on the lagged debt-to-GDP ratio including the control variables YVAR/output gap and GVAR/expenditure gap:

$$
\text { 'Transfers' }{ }_{\text {it }}=\alpha \text { 'Public Debt' }{ }_{\text {it- } 1}+\sum \beta_{1} Z_{\text {it }}+\eta_{i}+\varepsilon_{t}+u_{i t}
$$

We estimate our model including and excluding the lagged dependent variable.

Table 7 shows the regression results for the US state governments. In column (1) we only include fixed period and fixed state effects and find a positive coefficient of the lagged debt-to-GDP ratio on transfers. The result indicates that the transfers-to-GDP ratio in period t increased by about 0.04 percentage points when the debt-to-GDP ratio in period t- 1 increased by one percentage point. The coefficient of the lagged debt-to-GDP ratio is significant at the 5\%-level. In column (2) we include the YVAR variable (output shortfall) because Sørensen, $\mathrm{Wu}$, and Yosha (2001) show that federal grants react countercyclically with respect to statelevel output fluctuations. The YVAR variable is significant at the $1 \%$-level and has the expected positive sign: When a state experienced an output shortfall, transfers increased. We also include the GVAR variable to control for temporary government spending because transfers in the United States are mainly conditional on spending. In column (3) we include the output gap variable and the expenditure variable. The coefficient of the lagged debt-toGDP ratio does not turn out to be statistically significant at conventional levels when we include the YVAR, GVAR, output gap and expenditure variables. In columns (4) to (6) we include the lagged dependent variable. The estimated coefficient of the lagged debt-to-GDP 
ratio decreases to 0.006 and is significant at the 5\%-level when we only include fixed time effects and fixed state effects (column 4). The coefficient of the lagged debt-to-GDP ratio does not turn out to be statistically significant at conventional levels when we control for output fluctuations and temporary government spending (columns 5 and 6).

Table 8 shows the regression results for the German state governments. The coefficient of the lagged debt-to-GDP ratio is statistically significant at the $1 \%$ level in columns (1) to (3) and at the 5\% level in columns (4) to (6). The coefficient of the YVAR variable has a positive sign and is significant at the $1 \%$-level in column (2). The output gap variable has a negative sign and is statistically significant at the 5\%-level in column (3). The YVAR and output gap variables describe the effect of the German fiscal equalization system because business cycle fluctuations are correlated with tax revenues. States with increasing tax revenues receive less transfers, while states with decreasing tax revenues receive more transfers. The GVAR and the expenditure gap variables (excluding fiscal transfers) do not turn out to be statistically significant in columns (2) and (3). In contrast to the United States, transfers in Germany are not conditional on expenditures. Inferences regarding the lagged debt-to-GDP ratio do not change when we include the lagged dependent variable. The GVAR and expenditure gap variables are statistically significant at the $10 \%$ level and have a negative sign when we include the lagged dependent variable in columns (5) and (6).

In our regression models shown in Tables 7 and 8 we just included the explanatory variables of the fiscal reaction function. We re-estimate the model including explanatory variables that are likely to influence transfers in the United States and Germany. Because the fiscal transfer systems in the USA and Germany differ, we employ two different models for the US states and the German states.

For the US states we control for the main indicators of the US transfer system following Larcinese, Rizzo, and Testa (2013): population, the share of young inhabitants (age 5-17), the share of old inhabitants (age above 65), real per capita personal income, the unemployment rate, and Senators per capita. We include the explanatory variables in period $\mathrm{t}-1$ because many transfer projects for period $\mathrm{t}$ are determined in period $\mathrm{t}-1$. We estimate the model including and excluding the lagged dependent variable.

Table 9 shows the results for the US states. In column (1) the estimated coefficient of the lagged debt-to-GDP ratio is positive and statistically significant at the 5\%-level. When the debt-to-GDP ratio increased by one percentage point, the transfers-to-GDP ratio increased by about 0.04 percentage points. When we include the lagged dependent variable the estimated coefficient of the lagged debt-to-GDP ratio is positive and statistically significant at the 1\%level (column 2). The coefficient of the lagged debt-to-GDP ratio is smaller when we include the lagged dependent variable. When the debt-to-GDP ratio increased by one percentage point, the transfers-to-GDP ratio increased by 0.008 percentage points. The regression model including the lagged dependent variable in column (2) is our preferred specification because federal grants regarding several policy fields may be relatively persistent over time (see Lee and Oppenheimer 1999, p. 172). The effects of the control variables are in line with Larcinese, Rizzo, and Testa (2013). The coefficient of the population size has a negative sign and is statistically significant at the $10 \%$-level. The coefficient of the share of young inhabitants has a negative sign and is statistically significant at the 5\%-level. The coefficient of the per capita income variable has a negative sign and is statistically significant at the $10 \%$-level. States with low per capita incomes received, for example, more public welfare grants. The coefficient of the unemployment rate has a positive sign and is statistically 
significant at the $10 \%$-level. States with high unemployment rates received, for example, more grants for the employment security administration.

We also estimate the model using five year averages. In column (3) the coefficient of the lagged debt-to-GDP ratio is positive and statistically significant at the $10 \%$-level. When we include the lagged dependent variable the coefficient of the lagged debt-to-GDP ratio does not turn out to be statistically significant at conventional levels (column 4).

To explain transfers in the German states we include the variable 'Tax power' describing the real per capita tax revenues in state i relative to the average real per capita tax revenues in all German states in period $t^{17}$ We include a time dummy variable which assumes the value one for the states Bremen and Saarland over the period 1994-2004 to control for the extra transfers Bremen and Saarland received following a judgment of the Supreme Court (see section 3.1). We estimate our model including and excluding the lagged dependent variable.

Table 10 shows the results for the West German states. In column (1) the estimated coefficient of the lagged debt-to-GDP ratio is positive and statistically significant at the 5\%level. When the debt-to-GDP ratio increased by one percentage point, the transfers-to-GDP ratio increased by about 0.04 percentage points. The coefficient of the variable 'Tax power' has a negative sign and is statistically significant at the $1 \%$-level. States with high per capita tax revenues received less transfers or have to pay transfers, states with low per capita tax revenues received more transfers. The time dummy variable for the states Bremen and Saarland over the period 1994-2004 is statistically significant at the 1\%-level and has a positive sign. The states Bremen and Saarland received more transfers over the period 19942004. In column (2) we include the lagged dependent variable. The coefficient of the lagged debt-to-GDP ratio is positive and statistically significant at the 5\%-level. The coefficient of the lagged debt-to-GDP ratio is smaller when we include the lagged dependent variable. When the debt-to-GDP ratio increased by one percentage point, the transfers-to-GDP ratio increased by 0.03 percentage points. The coefficient of the 'Tax power' variable does not turn out to be statistically significant when we include the lagged dependent variable. The regression model without the lagged dependent variable in column (1), however, describes our preferred specification for the West German states. Transfers are calculated in every individual period.We also estimate the model using five year averages. The coefficient of the lagged debt-to-GDP ratio does not turn out to be statistically significant at conventional levels (columns 3 and 4).

What may explain the positive correlation between lagged debt and intergovernmental transfers? Since debt is not an explicit determinant of transfers, one may wonder how rules for transfers have evolved over time to benefit indebted states and implicitly subsidizing debts. We indeed interpret our findings showing that the fiscal transfers in the United States and Germany provide the states with incentives to increase spending and are not incentive compatible. Designing an incentive compatible fiscal transfer system would require that politicians cut transfers. Politicians in states which receive a great amount of fiscal transfers are however not likely to re-design the transfer system. Politicians at the federal level fear to lose votes by cutting transfers, especially by voters from states which receive a great amount of transfers. In Germany, politicians from donating states such as Bavaria and Hesse wish to reform the fiscal equalization scheme, but do not have political majorities.

\footnotetext{
${ }^{17}$ We compute tax revenues per capita as $100 \%$ of state government tax revenues and $64 \%$ of municipal tax revenues. In the city states Bremen and Hamburg, inhabitants are weigthed by $135 \%$.
} 


\subsubsection{Robustness tests}

Public debt may have a non-linear influence on the primary surplus. ${ }^{18}$ We account for possible nonlinearities and thus distinguish between reactions of the primary surplus to debt at different levels of debt by including a linear, a quadratic and a cubic term of the debt-toGDP ratio in the fiscal reaction function. For the US states the quadratic and cubic terms of the lagged debt-to-GDP ratio do not turn out to be statistically significant neither when we use the primary surplus 1 nor when we use the primary surplus 2 as the dependent variable. For the West German states the coefficient of the quadratic term of the lagged debt-to-GDP ratio has a positive sign and is statistically significant at the $10 \%$-level and the coefficient of the cubic terms of the debt-to-GDP ratio has a negative sign and is statistically significant at the $10 \%$-level when we use the primary surplus 1 as the dependent variable. The marginal response of the primary surplus to changes in the debt-to-GDP ratio seems to increase when the debt-to-GDP ratio increases. At very high debt-to-GDP ratios (about more than 48\%), however, the influence on the primary surplus on lagged debt decreased. ${ }^{19}$ Using the primary surplus 2 the quadratic and cubic terms of the debt-to-GDP ratio do not turn out to be statistically significant.

We estimate the models including municipal budgets. Local governments are creations of the states and bondholders and rating agencies tend to hold states responsible for troubled municipalities. Municipal debts in the United States are substantial and greater than state debts in many cases. The average debt-to-GDP ratio of the US state and local governments in our sample is $15.0 \%$. The average debt-to-GDP ratio of the West German state including municipalities in our sample is $24.4 \%$.

For the US state and municipal governments the lagged debt-to-GDP ratio had a positive influence on the primary surplus 1 . The coefficient is about 0.03 when we do not include the lagged dependent variable and about 0.02 when we include the lagged dependent variable. Using the primary surplus 2 as dependent variable the coefficient of the lagged debtto-GDP ratio is significant at the $10 \%$-level in three out of our 12 specifications and takes a value of about 0.01 . The lagged-debt-to-GDP ratio had a positive and statistically significant influence at the 10\%-level on the net transfer-to-GDP ratio when we include fixed time effects and fixed period effects. When we include the explanatory variables of the fiscal reaction function the estimated coefficient of the lagged debt-to-GDP ratio does not turn out to be statistically significant at conventional levels. When we include the explanatory variables that are likely to influence transfers in the United States the estimated coefficient of the lagged debt-to-GDP ratio is statistically significant at the $10 \%$-level when we include the lagged dependent variable. Inferences regarding our results for the West German state governments do not change when we include municipal budgets.

Fiscal institutions may influence the primary surpluses in the US states. ${ }^{20}$ Because we have included fixed state effects in our baseline model, we did not include variables describing fiscal institutions which do not vary over time. We estimate the fiscal reaction function for the US states without fixed state effects and included variables measuring fiscal

\footnotetext{
${ }^{18}$ Bohn (1998) finds an increasing marginal response of the primary surplus to changes in the debt-to-GDP ratio for the US federal government. Ghosh et al. (2013) find a cubic reaction function of the primary surplus-to-GDP ratio in period t to the debt-to-GDP ratio in period t- 1 in a panel of 23 advanced economies over the period 1970-2007. Checherita-Westphal and Rother (2012) find a quadratic reaction function of economic growth to the debt-to-GDP ratio in a panel of 12 euro area countries over the period 1970-2008.

${ }^{19}$ In our sample we have only six observations with debt-to-GDP ratios above $48 \%$.

${ }^{20}$ For a survey on fiscal institutions in the US states, see Besley and Case (2003).
} 
institutions (Poterba and Rueben 1999). We include a balanced-budget-rule dummy variable which assumes the value one for states which may not carry over a deficit into the next fiscal year or biennium, and the value zero for states which may carry over a deficit. ${ }^{21}$ We also consider whether a state has a tax or expenditure limit (TEL). ${ }^{22}$ TELs limit the growth rate of expenditures or revenues on indicators such as the growth rate of personal income (Poterba and Rueben 1999). Including the variables measuring fiscal institutions does not change the inferences regarding the debt-to-GDP ratio.

In Germany, federal law determines social security expenditures to a large extent (Seitz 2000). We compute the primary surplus 1 (standard definition) and the primary surplus 2 (excluding transfers) excluding social security expenditures. Inferences regarding the lagged debt-to-GDP-ratio do not change.

We test whether inferences change when including/excluding individual states (jackknife tests). When we exclude New Mexico, the estimated coefficient of the lagged debt-to-GDP ratio turns out to be statistically significant at the 10\%-level in columns (2) and (3) and at the 5\%-level in columns (4) to (6) in Table 4a. When we exclude Montana, the estimated coefficient of the lagged debt-to-GDP ratio turns out to be statistically significant at the $10 \%$-level in columns (4) to (6) in Table 4a and column (1) in Table 4b. When we exclude Bremen, the estimated coefficient of the lagged debt-to-GDP ratio does not turn out to be statistically significant at conventional levels in columns (4) to (6) in Table 8. When we exclude Bremen or Saarland, the estimated coefficient of the lagged debt-to-GDP ratio does not turn out to be statistically significant at conventional levels in columns (1) and (2) in Table 10 .

\section{CONCLUSION}

We test whether the fiscal behavior of the US and German states is sustainable and show that the results of standard fiscal sustainability tests depend on whether fiscal transfers are taken into account. In particular, we examine whether the debt-to-GDP-ratio had a positive influence on the primary surplus (Bohn-model) and distinguish between different measures of the primary surplus. If fiscal transfers are not included in the primary surplus, the test results do not indicate that the US and German state governments pursued sustainable fiscal policies. We also show that fiscal transfers were positively related with debt, indicating that intergovernmental transfers have implicitly subsidized debts in the states.

Our findings are compatible with findings of empirical studies employing vector error-correction models to investigate how fiscal transfers influence fiscal performance. Buettner and Wildasin (2006) and Buettner (2009) use data for German and US municipalities and show that fiscal transfers give rise to fiscal adjustment.

From our analysis we derive policy implications which would also apply to the design of a European fiscal union: fiscal transfers schemes need to be incentive compatible and politically sustainable. It appears that transfers sugarcoat the budgets of governments that do not attempt to keep their budgets balanced. Fiscal transfers therefore provide perverse incentives. Buettner (2006) arrives at similar results for transfers on the municipality level. Beetsma and Bovenberg (2001) show that a monetary union should not come along with a

\footnotetext{
${ }^{21}$ We use data on balanced budget rules from ACIR (1987) and NCSL (2010a).

${ }^{22}$ We use data on tax and expenditure limits from Poterba and Rueben (1999) and NCSL (2010b).
} 
fiscal union in which international transfers stabilize country-specific shocks when the fiscal discipline among the member states is low.

The German fiscal equalization scheme in particular reduces the incentives of the states to increase their own tax revenues. When the tax revenue increases in a state that receives fiscal transfers, the transfers received decrease. By contrast, when the tax revenue increases in a state that pays fiscal transfers, the transfers paid increase. Baretti, Huber, and Lichtblau (2001) portray three examples on how the German fiscal equalization scheme reduces the incentives of the states to increase their own tax revenues. First, empirical evidence shows that the fiscal equalization scheme reduces the states' tax enforcement efficiency (see also Baretti, Huber, and Lichtblau 2002, Herwartz and Theilen Forthcoming). Second, the fiscal transfers constrain government activities to enhance economic growth (e.g. infrastructure investments). The state has to bear the cost of the investment but the additional tax revenues resulting from higher economic growth are absorbed by the equalization scheme. Third, fiscal equalization schemes distort the states' incentives to attract companies to increase tax revenues. An important issue for future research is to design incentive compatible fiscal transfer systems.

When fiscal policies of federal states are shown to be only sustainable when fiscal transfers are assumed to be also forthcoming in the future, the question arises to which extent governments paying fiscal transfers are willing and able to proceed paying. The issue then is not whether fiscal policy is sustainable but whether fiscal transfer schemes are politically sustainable.

\section{ACKNOWLEDGMENTS}

We are grateful for comments from Christian Bjørnskov, Feler Bose, Richard Jong-A-Pin, Sergio Galletta, Helmut Herwartz, James Poterba, Malte Rengel, Uwe Sunde, Andrey Timofeev, and participants of the Money and Banking Workshop 2012 in Rimini, the Public Economics Workshop 2012 in Munich, the Economics Workshop 2013 in Trier, the Public Choice Society Meeting 2013 in New Orleans, the European Public Choice Society Meeting 2013 in Zurich, the CESifo Area Conference on Public Sector Economics 2013 in Munich, the Conference on Fiscal Rules 2013 in Montreal, the Research Seminar at the University of Nuremberg 2103, the Annual Congress of the IIPF 2013 in Taormina, and two anonymous referees. Heinrich Ursprung helped us to improve our paper. Miriam Breckner, Gavin Goy, Jakob Müller and Ha Quyen Ngo provided excellent research assistance. 


\section{LITERATURE CITED}

ACIR. (1987) "Fiscal Discipline in the Federal System: National Reform and the Experience of the States.” Advisory Commission on Intergovernmental Relations, July 1987.

Ahmed, Shaghil, and John H. Rogers. (1995) "Government Budget Deficits and Trade Deficits: Are Present Value Constraints Satisfied in Long-Term Data?” Journal of Monetary Economics, 36, 351-374.

Arellano, Manuel, and Olympia Bover. (1995) “Another Look at the Instrumental Variable Estimation of Error-Components Models.” Journal of Econometrics, 68, 29-51.

Baretti, Christian, Bernd Huber, and Karl Lichtblau. (2001) "Weniger Wachstum und Steueraufkommen durch den Finanzausgleich.” Wirtschaftsdienst, 81, 38-44.

Baretti, Christian, Bernd Huber, and Karl Lichtblau. (2002) "A Tax on Tax Revenue: The Incentive Effects of Equalizing Transfers: Evidence from Germany.” International Tax and Public Finance, 9, 631-649.

Barro, Robert J. (1979) “On the Determination of the Public Debt.” Journal of Political Economy, 87, 940-971.

Barro, Robert J. (1986) “U.S. Deficits Since World War I.” Scandinavian Journal of Economics, 88, 195-222.

Bazzi, Samuel, and Michael A. Clemens. (2013) "Blunt Instruments: Avoiding Common Pitfalls in Identifying the Causes of Economic Growth.” American Economic Journal: Macroeconomics, 5, 152-186.

Beetsma, Roel M. W. J., and A. Lans Bovenberg. (2001) "The Optimality of a Monetary Union without a Fiscal Union.” Journal of Money, Credit and Banking, 33, 179-204.

Besley, Timothy, and Anne Case. (2003) "Political Institutions and Policy Choices: Evidence from the United States.” Journal of Economic Literature, 41, 7-73.

Blanchard, Olivier J. (1984) "Current and Anticipated Deficits, Interest Rates and Economic Activity.” European Economic Review, 25, 7-27.

Blundell, Richard W., and Stephen R. Bond. (1998) "Initial Conditions and Moment Restrictions in Dynamic Panel Data Models.” Journal of Econometrics, 87, 115-143.

Bohn, Henning. (1995) “The Sustainability of Budget Deficits in a Stochastic Economy." Journal of Money, Credit and Banking, 27, 257-271.

Bohn, Henning. (1998) “The Behavior of U.S. Public Debt and Deficits.” Quarterly Journal of Economics, 113, 949-963.

Bohn, Henning. (2007) “Are Stationarity and Cointegration Restrictions Really Necessary for the Intertemporal Budget Constraint?” Journal of Monetary Economics, 54, 18371847.

Bohn, Henning. (2008) “The Sustainability of Fiscal Policy in the United States." In Sustainability of Public Debt, edited by Reinhard Neck and Jan-Egbert Sturm, pp. 1549. Cambridge, MA: MIT Press. 
Bohn, Henning, and Robert P. Inman. (1996) "Balanced-Budget Rules and Public Deficits: Evidence from the U.S. States.” Carnegie-Rochester Conference Series on Public Policy, 45, 13-76.

Bordo, Michael D., Lars Jonung, and Agnieszka Markiewicz. (2013) “A Fiscal Union for the Euro: Some Lessons from History.” CESifo Economic Studies, 59, 449-488.

Buettner, Thiess. (2006) "The Incentive Effect of Fiscal Equalization Transfers on Tax Policy.” Journal of Public Economics, 90, 477-497.

Buettner, Thiess. (2009) "The Contribution of Equalization Transfers to Fiscal Adjustment: Empirical Results for German Municipalities and a US-German Comparison.” Journal of Comparative Economics, 37, 477-497.

Buettner, Thiess, and David E. Wildasin. (2006) “The Dynamics of Municipal Fiscal Adjustment.” Journal of Public Economics, 90, 1115-1132.

Bundesministerium der Finanzen. (2012) "Der bundesstaatliche Finanzausgleich.” http://www.bundesfinanzministerium.de/Content/DE/Standardartikel/Themen/Oeffent liche_Finanzen/Foederale_Finanzbeziehungen/Laenderfinanzausgleich/laenderfinanza usgleich-anlage01.html.

Burret, Heiko T., Lars P. Feld, and Ekkehard A. Köhler. (2013) "Sustainability of Public Debt in Germany - Historical Considerations and Time Series Evidence.” Jahrbücher für Nationalökonomie und Statistik/ Journal of Economics and Statistics, 233, 291335.

Byrne, Joseph P., Norbert Fiess, and Ronald MacDonald. (2011) "The Global Dimension to Fiscal Sustainability.” Journal of Macroeconomics, 33, 137-150.

Canzoneri, Matthew B., Robert E. Cumby, and Behzad T. Diba. (2001) "Is the Price Level Determined by the Needs of Fiscal Solvency?” American Economic Review, 91, 12211238.

Cavaliere, Giuseppe, and Fang Xu. (2014) “Testing for Unit Roots in Bounded Time Series.” Journal of Econometrics, 178, 259-272.

Checherita-Westphal, Cristina, and Philipp Rother. (2012) "The Impact of High Government Debt on Economic Growth and its Channels: An Empirical Investigation for the Euro Area.” European Economic Review, 56, 1392-1405.

Claeys, Peter, Raúl Ramos, and Jordi Suriňach. (2008) Fiscal Sustainability Across Government Tiers.” International Economics and Economic Policy, 5, 139-163.

Fincke, Bettina, and Alfred Greiner. (2011) "Debt Sustainability in Germany: Empirical Evidence for Federal States.” International Journal of Sustainable Economy, 3, 235254.

Fincke, Bettina, and Alfred Greiner. (2012) "How to Assess Debt Sustainability? Some Theory and Empirical Evidence for Selected Euro Area Countries.” Applied Economics, 44, 3717-3724. 
GAO. (1993) “Balanced Budget Requirements.” Briefing Report to the Chairman, Committee on the Budget, House of Representatives, United States Government Accountability Office, March 1993.

GAO. (2009) "Formula grants." Report to Congressional Requesters, United States Government Accountability Office, December 2009.

GAO. (2012) “Grants to State and Local governments.” Report to Congressional Requesters, United States Government Accountability Office, September 2012.

Ghosh, Atish. R., Jun I. Kim, Enrique G. Mendoza, Jonathan D. Ostry, and Mahvash S. Qureshi. (2013) "Fiscal Fatigue, Fiscal Space and Debt Sustainability in Advanced Economies.” Economic Journal, 123, F4-F30.

Hamilton, James D., and Marjorie A. Flavin. (1986) "On the Limitations of Government Borrowing: A Framework for Empirical Testing.” American Economic Review, 76, 808-819.

Herwartz, Helmut, and Bernd Theilen. (Forthcoming) "On the Political and Fiscal Determinants of Income Redistribution Under Federalism and Democracy: Evidence from Germany.“ Public Choice.

Herwartz, Helmut, and Fang Xu. (2008) "Reviewing the Sustainability/Stationarity of Current Account Imbalances with Tests for Bounded Integration.” The Manchester School, 76, 267-278.

Herzog, Bodo. (2010) “Anwendung des Nachhaltigkeitsansatzes von Bohn zur Etablierung eines Frühindikators in den öffentlichen Finanzen.” Kredit und Kapital, 42, 183-206.

Heun, Werner. (2014) "Balanced Budget Requirements and Debt Brakes Feasibility and Enforcement.” German Economic Review, 15, 100-115.

Huber, Peter J. (1967) “The Behavior of Maximum Likelihood Estimates Under Nonstandard Conditions." In Proceedings of the Fifth Berkeley Symposium on Mathematical Statistics and Probability, Volume 1: Statistics, edited by Lucien M. Le Cam and Jerzey Neyman, pp. 221-233. Berkeley, CA: University of California Press.

Kenen, Peter B. (1969) "The Theory of Optimum Currency Areas: An Eclectic View.” In Monetary Problems of the International Economy, edited by Robert A. Mundell and Alexander K. Swoboda, pp. 41-60. Chicago, IL: University of Chicago Press.

Koester, Gerrit B., and Christoph Priesmeier. (2013) "Does Wagner's Law Ruin the Sustainability of German Public Finances?” FinanzArchiv: Public Finance Analysis, 69, 256-288.

Krugman, Paul. (2012) "Revenge of the Optimum Currency Area." In NBER Macroeconomics Annual 2012, Volume 27, edited by Daron Acemoglu, Jonathan Parker, and Michael Woodford, pp. 439-448. Chicago, IL: University of Chicago Press.

Kitterer, Wolfgang. (2007) "Nachhaltige Finanz- und Investitionspolitik der Bundesländer.” Perspektiven der Wirtschaftspolitik, 8, 53-83. 
Kitterer, Wolfgang, and Jan Finken. (2006) “Zur Nachhaltigkeit der Länderhaushalte - Eine empirische Analyse.” Finanzwissenschaftliche Diskussionsbeiträge/ Finanzwissenschaftliches Forschungsinstitut an der Universität zu Köln No. 06-7, Universität zu Köln, Dezember 2006.

Larcinese, Valentino, Leonzio Rizzo, and Cecilia Testa. (2013) "Why Do Small States Receive More Federal Money? U.S. Senate Representation and the Allocation of Federal Budget.” Economics and Politics, 25, 257-282.

Lee, Frances. E., and Bruce I. Oppenheimer. (1999) Sizing Up the Senate. The Unequal Consequences of Equal Representation. Chicago, IL: University of Chicago Press.

Mahdavi, Saeid, and Joakim Westerlund. (2011) "Fiscal Stringency and Fiscal Sustainability: Panel Evidence from the American State and Local Governments.” Journal of Policy Modeling, 33, 953-969.

Masson, Paul R. (1996) “Fiscal Dimensions of Emu.” Economic Journal, 106, 996-1004.

Mendoza, Enrique G., and Jonathan D. Ostry. (2008) "International Evidence on Fiscal Solvency: Is Fiscal Policy ‘Responsible’?” Journal of Monetary Economics, 55, 10811093.

NCSL. (2010a) “NCSL Fiscal Brief: State Balance Budget Provisions.” National Conference of State Legislatures, October 2010.

NCSL. (2010b) “State Tax and Expenditure Limits - 2010.” National Conference of State Legislatures, http://www.ncsl.org/research/fiscal-policy/state-tax-and-expenditurelimits-2010.aspx.

Nickell, Stephen. (1981) “Biases in Dynamic Models with Fixed Effects.” Econometrica, 49, 1417-1426.

Poterba, James M. (1994) "State Responses to Fiscal Crises: The Effects of Budgetary Institutions and Politics.” Journal of Political Economy, 102, 799-821.

Poterba, James M. (1996) "Budget Institutions and Fiscal Policy in the U.S. States." American Economic Review Papers and Proceedings, 86, 395-400.

Poterba, James M., and Kim Rueben. (1999) "State Fiscal Institutions and the U.S. Municipal Bond Market.” In Fiscal Institutions and Fiscal Performance, edited by James M. Poterba and Jürgen von Hagen, pp.181-207. Chicago, IL: University of Chicago Press.

Prohl, Silika, and Joakim Westerlund. (2009) "Using Panel Data to Test for Fiscal Sustainability within the European Union.” FinanzArchiv: Public Finance Analysis, 65, 246-269.

Quintos, Carmela E. (1995) "Sustainability of the Deficit Process with Structural Shifts." Journal of Business \& Economic Statistics, 13, 409-417.

Rodden, Jonathan A. (2003) "Soft Budget Constraints and German Federalism.” In Fiscal Decentralization and the Challenge of Hard Budget Constraints, edited by Jonathan A. Rodden, Gunnar S. Eskeland and Jennie I. Litvack, pp. 161-186. Cambridge, MA: MIT Press. 
Roodman, David. (2006) "How to Do Xtabond2: An Introduction to 'Difference' and 'System' GMM in Stata.” Center for Global Development Working Paper 103, Center for Global Development, December 2006.

Roodman, David. (2009) “A Note on the Theme of Too Many Instruments.” Oxford Bulletin of Economics and Statistics, 71, 135-158.

Sala-i-Martin, Xavier, and Jeffrey Sachs. (1992) "Fiscal Federalism and Optimum Currency Areas: Evidence for Europe from the United States.” CEPR Discussion Papers 632, Centre for Economic Policy Research, March 1992.

Seitz, Helmut. (2000) “Subnational Government Bailouts in Germany.” Inter-American Development Bank Research Paper No. R-396, Inter-American Development Bank, November 2000.

Sørensen, Bent E., Lisa Wu, and Oved Yosha. (2001) "Output Fluctuations and Fiscal Policy: U.S. State and Local Governments 1978-1994.” European Economic Review, 45, 1271-1310.

Stock, James H., and Mark W. Watson. (2008) "Heteroskedasticity-Robust Standard Errors for Fixed Effect Panel Data Regression.” Econometrica, 76, 155-174.

Trehan, Bharat, and Carl E. Walsh. (1988) "Common Trends, the Government's Budget Constraint, and Revenue Smoothing." Journal of Economic Dynamics and Control, 12, 425-444.

Trehan, Bharat and Carl E. Walsh. (1991) “Testing Intertemporal Budget Constraints: Theory and Applications to US Federal Budget and Current Account Deficits.” Journal of Money, Credit and Banking, 23, 206-223.

White, Halbert. (1980) "A Heteroskedasticity-consistent Covariance Matrix Estimator and a Direct Test for Heteroskedasticity.” Econometrica, 48, 817-838.

White, Halbert. (1982) "Maximum Likelihood Estimation of Misspecified Models." Econometrica, 50, 1-25.

Wilcox, David W. (1989) "The Sustainability of Governments Deficits: Implications of the Present-Value Borrowing Constraint.” Journal of Money, Credit and Banking, 21, 291-306.

Windmeijer, Frank. (2005) “A Finite Sample Correction for the Variance of Linear Efficient Two-Step GMM Estimators.” Journal of Econometrics, 126, 25-51.

Woodford, Michael. (1998) “Comment on Cochran's 'A Frictionless View of U.S. Inflation'.” In NBER Macroeconomics Annual 1998, Volume 13, edited by Ben S. Bernanke and Julio J. Rotemberg, pp. 390-418. Cambridge, MA: MIT Press. 
Table 1a: Data sources (US states)

\begin{tabular}{l|l}
\hline \hline Variable & Data source \\
\hline GDP, real GDP & U.S. Bureau of Economic Analysis \\
\hline $\begin{array}{l}\text { Debt, Revenues, Expenditures, } \\
\text { Interest payments, Transfers }\end{array}$ & U.S. Census Bureau, State and Local Government Finances \\
\hline Population, age structure & $\begin{array}{l}\text { U.S. Census Bureau, Population Division, Intercensal Estimates of the } \\
\text { Resident Population }\end{array}$ \\
\hline Personal Income & U.S. Bureau of Economic Analysis, Personal income summary \\
\hline Unemployment rate & $\begin{array}{l}\text { U.S. Bureau of Labor Statistics, Employment status of the civilian } \\
\text { noninstitutional population, annual averages }\end{array}$ \\
\hline \hline
\end{tabular}

Note: In 1997, the Bureau of Economic Analysis changed the method on how to estimate GDP from the Standard Industrial Classification (SIC) to the North American Industry Classification System (NAICS). On average GDP in the US states decreased by $1 \%$ after the change in the estimation procedure. We control for the change in the estimation procedure with fixed time effects. For the years 2001 and 2003 finance data of the local governments are not available. We interpolate the finance data to obtain values for the years 2001 and 2003. 
Table 1b: Data sources (West German states)

\begin{tabular}{l|l}
\hline \hline Variable & Data source \\
\hline GDP, real GDP & Research Group “Volkswirtschaftliche Gesamtrechnung der Länder” \\
\hline Debt & German Federal Statistical Office (Fachserie 14 Reihe 5) \\
\hline $\begin{array}{l}\text { Revenues, Expenditures, } \\
\text { Interest payments, Tax revenues }\end{array}$ & German Federal Statistical Office (Fachserie 14 Reihe 3.1) \\
\hline Transfers & German Federal Statistical Office \\
\hline \hline
\end{tabular}

Note: We consider credit market debt (Kreditmarktschulden) which accounts for the largest share on debt, short-term financial instruments (Kassenkredite), which have become more important to balance budgets since the year 2000, and liabilities to the public sector. 
Table 2a: Summary statistics (US states)

\begin{tabular}{l|c|c|c|c|c}
\hline \hline Variable & Observations & Mean & Std. dev. & Min & Max \\
\hline Debt-to-GDP ratio & 1,551 & 0.064 & 0.039 & 0.003 & 0.228 \\
\hline Primary surplus 1-to-GDP ratio & 1,551 & 0.005 & 0.006 & -0.026 & 0.033 \\
\hline Primary surplus 2-to-GDP ratio & 1,551 & -0.024 & 0.013 & -0.100 & 0.015 \\
\hline YVAR & 1,551 & 0.000 & 0.003 & -0.010 & 0.014 \\
\hline GVAR & 1,551 & -0.000 & 0.004 & -0.018 & 0.024 \\
\hline Output gap & 1,551 & 0.000 & 0.028 & -0.112 & 0.105 \\
\hline Expenditure gap & 1,551 & -0.000 & 0.004 & -0.018 & 0.024 \\
\hline Transfers-to-GDP ratio & 1,551 & 0.029 & 0.011 & 0.011 & 0.097 \\
\hline Population & 1,551 & 0.548 & 0.573 & 0.049 & 3.696 \\
\hline Real per capita personal income & 1,551 & 2.739 & 0.714 & 1.344 & 5.259 \\
\hline Unemployment rate & 1,551 & 0.059 & 0.020 & 0.023 & 0.174 \\
\hline Population share 5-17 & 1,551 & 0.192 & 0.019 & 0.154 & 0.266 \\
\hline Population share $>65$ & 1,551 & 0.124 & 0.018 & 0.075 & 0.185 \\
\hline Senators per capita & 1,551 & 0.880 & 0.870 & 0.054 & 4.065 \\
\hline \hline
\end{tabular}

Note: Population in 10 million. Senators per capita denotes Senators per 10 million inhabitants. Per capita personal income in 10.000 Dollar. Annual data for 47 US states (Alaska, Hawaii, Wyoming excluded) over the period 1978-2010 (debt, population, population shares, personal income, unemployment rate and Senators over the period 1977-2009). 
Table 2b: Summary statistics (West German states)

\begin{tabular}{l|c|c|c|c|c}
\hline \hline Variable & Observations & Mean & Std. dev. & Min & Max \\
\hline Debt-to-GDP ratio & 360 & 0.190 & 0.106 & 0.037 & 0.606 \\
\hline Primary surplus 1-to-GDP ratio & 360 & -0.000 & 0.010 & -0.043 & 0.044 \\
\hline Primary surplus 2-to-GDP ratio & 360 & -0.006 & 0.014 & -0.060 & 0.022 \\
\hline YVAR & 360 & 0.000 & 0.003 & -0.012 & 0.010 \\
\hline GVAR & 360 & 0.000 & 0.004 & -0.014 & 0.018 \\
\hline Output gap & 360 & -0.000 & 0.022 & -0.055 & 0.065 \\
\hline Expenditure gap & 360 & 0.000 & 0.004 & -0.014 & 0.018 \\
\hline Transfers-to-GDP ratio & 360 & 0.006 & 0.015 & -0.015 & 0.073 \\
\hline Tax power & 360 & 1.062 & 0.144 & 0.825 & 1.493 \\
\hline \hline
\end{tabular}

Note: Tax power describes the real per capita tax revenues in one state relative to the average real per capita tax revenues in all German states. Annual data for 10 West German states over the period 1975-2010 (debt over the period 1974-2009). 
Table 3a: Fiscal reaction functions including fiscal transfers in the US states

\begin{tabular}{|c|c|c|c|c|c|c|}
\hline Variables & (1) & (2) & (3) & (4) & (5) & (6) \\
\hline Lagged debt-to-GDP ratio & $\begin{array}{c}0.053 * * * \\
(0.014)\end{array}$ & $\begin{array}{c}0.055^{* * *} \\
(0.015)\end{array}$ & $\begin{array}{c}0.055^{* * *} \\
(0.015)\end{array}$ & $\begin{array}{c}0.030 * * * \\
(0.008)\end{array}$ & $\begin{array}{c}0.031 * * * \\
(0.010)\end{array}$ & $\begin{array}{c}0.030 * * * \\
(0.010)\end{array}$ \\
\hline YVAR & & $\begin{array}{c}-0.278^{* * *} \\
(0.072)\end{array}$ & & & $\begin{array}{c}-0.138^{* *} \\
(0.054)\end{array}$ & \\
\hline GVAR & & $\begin{array}{c}-0.588 * * * \\
(0.038)\end{array}$ & & & $\begin{array}{c}-0.525^{* * *} \\
(0.038)\end{array}$ & \\
\hline Output gap & & & $\begin{array}{c}0.026 * * * \\
(0.007)\end{array}$ & & & $\begin{array}{c}0.011^{* *} \\
(0.005)\end{array}$ \\
\hline Expenditure gap & & & $\begin{array}{c}-0.580^{* * *} \\
(0.039)\end{array}$ & & & $\begin{array}{c}-0.519 * * * \\
(0.038)\end{array}$ \\
\hline Lagged dependent variable & & & & $\begin{array}{c}0.577 * * * \\
(0.069)\end{array}$ & $\begin{array}{c}0.545^{* * *} \\
(0.075)\end{array}$ & $\begin{array}{c}0.546 * * * \\
(0.076)\end{array}$ \\
\hline Fixed time effects & Yes & Yes & Yes & Yes & Yes & Yes \\
\hline Fixed state effects & Yes & Yes & Yes & Yes & Yes & Yes \\
\hline R-squared (overall) & 0.317 & 0.424 & 0.423 & 0.633 & 0.713 & 0.712 \\
\hline Number of states & 47 & 47 & 47 & 47 & 47 & 47 \\
\hline Number of observations & 1,551 & 1,551 & 1,551 & 1,551 & 1,551 & 1,551 \\
\hline
\end{tabular}

Dependent variable: Primary surplus 1-to-GDP ratio (standard measure)

Note: OLS with standard errors robust to heteroskedasticity (Huber/White/sandwich standard errors) in parentheses;

$* * *, * *$ and $*$ denote significance at the $1 \%, 5 \%$ and $10 \%$ levels;

The panel is balanced with samples for 47 US states (Alaska, Hawaii, Wyoming excluded) covering the period 1978-2010. 
Table 3b: Fiscal reaction functions including fiscal transfers in the US states

\begin{tabular}{|c|c|c|c|c|c|c|}
\hline Variables & (1) & (2) & (3) & (4) & (5) & (6) \\
\hline Lagged debt-to-GDP ratio & $\begin{array}{l}0.042^{* * *} \\
(0.007)\end{array}$ & $\begin{array}{c}0.045^{* * *} \\
(0.009)\end{array}$ & $\begin{array}{l}0.045^{* * *} \\
(0.009)\end{array}$ & $\begin{array}{l}0.045^{* *} \\
(0.018)\end{array}$ & $\begin{array}{c}0.050^{* * *} \\
(0.014)\end{array}$ & $\begin{array}{l}0.050 * * * \\
(0.014)\end{array}$ \\
\hline YVAR & & $\begin{array}{c}-0.229 * * * \\
(0.086)\end{array}$ & & & $\begin{array}{c}-0.253 * * * \\
(0.083)\end{array}$ & \\
\hline GVAR & & $\begin{array}{c}-0.610 * * * \\
(0.056)\end{array}$ & & & $\begin{array}{c}-0.616^{* * *} \\
(0.047)\end{array}$ & \\
\hline Output gap & & & $\begin{array}{c}0.020^{* * *} \\
(0.007)\end{array}$ & & & $\begin{array}{c}0.022 * * * \\
(0.007)\end{array}$ \\
\hline Expenditure gap & & & $\begin{array}{c}-0.605 * * * \\
(0.054)\end{array}$ & & & $\begin{array}{c}-0.609 * * * \\
(0.046)\end{array}$ \\
\hline Lagged dependent variable & $\begin{array}{c}0.526 * * * \\
(0.061)\end{array}$ & $\begin{array}{c}0.412 * * * \\
(0.072)\end{array}$ & $\begin{array}{c}0.411^{* * *} \\
(0.071)\end{array}$ & $\begin{array}{c}0.537 * * * \\
(0.060)\end{array}$ & $\begin{array}{c}0.418^{* * *} \\
(0.047)\end{array}$ & $\begin{array}{c}0.415^{* * *} \\
(0.046)\end{array}$ \\
\hline Fixed time effects & Yes & Yes & Yes & Yes & Yes & Yes \\
\hline Fixed state effects & Yes & Yes & Yes & Yes & Yes & Yes \\
\hline $\begin{array}{l}\text { Lagged dependent variable } \\
\text { endogenous }\end{array}$ & Yes & Yes & Yes & Yes & Yes & Yes \\
\hline $\begin{array}{l}\text { Lagged debt-to-GDP ratio } \\
\text { endogenous }\end{array}$ & No & No & No & Yes & Yes & Yes \\
\hline AR(1), p-value & 0.001 & 0.001 & 0.001 & 0.001 & 0.001 & 0.001 \\
\hline AR(2), p-value & 0.167 & 0.124 & 0.140 & 0.160 & 0.111 & 0.129 \\
\hline Hansen, p-value & 0.075 & 0.061 & 0.065 & 0.023 & 0.364 & 0.376 \\
\hline Number of intruments & 40 & 42 & 42 & 45 & 47 & 47 \\
\hline Number of states & 47 & 47 & 47 & 47 & 47 & 47 \\
\hline Number of observations & 1,551 & 1,551 & 1,551 & 1,551 & 1,551 & 1,551 \\
\hline
\end{tabular}

Dependent variable: Primary surplus 1-to-GDP ratio (standard measure)

Note: Two-step system GMM with robust standard errors in parantheses; instruments collapsed and limited to the $5^{\text {th }}$ lag; ***, ** and * denote significance at the $1 \%, 5 \%$ and $10 \%$ levels;

The panel is balanced with samples for 47 US states (Alaska, Hawaii, Wyoming excluded) covering the period 1978-2010. 
Table 4a: Fiscal reaction functions excluding fiscal transfers in the US states

\begin{tabular}{|c|c|c|c|c|c|c|}
\hline Variables & (1) & (2) & (3) & (4) & (5) & (6) \\
\hline Lagged debt-to-GDP ratio & $\begin{array}{c}0.012 \\
(0.027)\end{array}$ & $\begin{array}{c}0.023 \\
(0.025)\end{array}$ & $\begin{array}{c}0.024 \\
(0.026)\end{array}$ & $\begin{array}{c}0.011 \\
(0.008)\end{array}$ & $\begin{array}{c}0.015 \\
(0.009)\end{array}$ & $\begin{array}{c}0.014 \\
(0.009)\end{array}$ \\
\hline YVAR & & $\begin{array}{c}-0.748 * * * \\
(0.080)\end{array}$ & & & $\begin{array}{c}-0.373 * * * \\
(0.047)\end{array}$ & \\
\hline GVAR & & $\begin{array}{c}-0.868^{* * *} \\
(0.040)\end{array}$ & & & $\begin{array}{c}-0.713 * * * \\
(0.035)\end{array}$ & \\
\hline Output gap & & & $\begin{array}{c}0.073 * * * \\
(0.008)\end{array}$ & & & $\begin{array}{c}0.033 * * * \\
(0.005)\end{array}$ \\
\hline Expenditure gap & & & $\begin{array}{c}-0.851^{* * *} \\
(0.045)\end{array}$ & & & $\begin{array}{c}-0.700^{* * *} \\
(0.037)\end{array}$ \\
\hline Lagged dependent variable & & & & $\begin{array}{c}0.758 * * * \\
(0.057)\end{array}$ & $\begin{array}{c}0.705^{* * *} \\
(0.071)\end{array}$ & $\begin{array}{c}0.706 * * * \\
(0.072)\end{array}$ \\
\hline Fixed time effects & Yes & Yes & Yes & Yes & Yes & Yes \\
\hline Fixed state effects & Yes & Yes & Yes & Yes & Yes & Yes \\
\hline R-squared (overall) & 0.327 & 0.388 & 0.387 & 0.861 & 0.889 & 0.889 \\
\hline Number of states & 47 & 47 & 47 & 47 & 47 & 47 \\
\hline Number of observations & 1,551 & 1,551 & 1,551 & 1,551 & 1,551 & 1,551 \\
\hline
\end{tabular}

Dependent variable: Primary surplus 2-to-GDP ratio (excluding fiscal transfers)

Note: OLS with standard errors robust to heteroskedasticity (Huber/White/sandwich standard errors) in parentheses;

$* * *, * *$ and $*$ denote significance at the $1 \%, 5 \%$ and $10 \%$ levels;

The panel is balanced with samples for 47 US states (Alaska, Hawaii, Wyoming excluded) covering the period 1978-2010. 
Table 4b: Fiscal reaction functions excluding fiscal transfers in the US states

\begin{tabular}{|c|c|c|c|c|c|c|}
\hline Variables & (1) & (2) & (3) & (4) & (5) & (6) \\
\hline Lagged debt-to-GDP ratio & $\begin{array}{c}0.010 \\
(0.012)\end{array}$ & $\begin{array}{c}0.010 \\
(0.018)\end{array}$ & $\begin{array}{c}0.009 \\
(0.018)\end{array}$ & $\begin{array}{c}0.035 \\
(0.023)\end{array}$ & $\begin{array}{c}0.032 \\
(0.032)\end{array}$ & $\begin{array}{c}0.030 \\
(0.032)\end{array}$ \\
\hline YVAR & & $\begin{array}{c}-0.489 * * * \\
(0.071)\end{array}$ & & & $\begin{array}{c}-0.503 * * * \\
(0.080)\end{array}$ & \\
\hline GVAR & & $\begin{array}{c}-0.815^{* * *} \\
(0.045)\end{array}$ & & & $\begin{array}{c}-0.816^{* * *} \\
(0.044)\end{array}$ & \\
\hline Output gap & & & $\begin{array}{c}0.046^{* * *} \\
(0.006)\end{array}$ & & & $\begin{array}{c}0.047^{* * *} \\
(0.006)\end{array}$ \\
\hline Expenditure gap & & & $\begin{array}{c}-0.810 * * * \\
(0.045)\end{array}$ & & & $\begin{array}{c}-0.807 * * * \\
(0.044)\end{array}$ \\
\hline Lagged dependent variable & $\begin{array}{c}0.722^{* * *} \\
(0.072)\end{array}$ & $\begin{array}{c}0.448^{* * *} \\
(0.086)\end{array}$ & $\begin{array}{c}0.444^{* * *} \\
(0.091)\end{array}$ & $\begin{array}{c}0.719 * * * \\
(0.069)\end{array}$ & $\begin{array}{c}0.455^{* * *} \\
(0.068)\end{array}$ & $\begin{array}{c}0.453^{* * *} \\
(0.072)\end{array}$ \\
\hline Fixed time effects & Yes & Yes & Yes & Yes & Yes & Yes \\
\hline Fixed state effects & Yes & Yes & Yes & Yes & Yes & Yes \\
\hline $\begin{array}{l}\text { Lagged dependent variable } \\
\text { endogenous }\end{array}$ & Yes & Yes & Yes & Yes & Yes & Yes \\
\hline $\begin{array}{l}\text { Lagged debt-to-GDP ratio } \\
\text { endogenous }\end{array}$ & No & No & No & Yes & Yes & Yes \\
\hline AR(1), p-value & 0.001 & 0.001 & 0.001 & 0.001 & 0.001 & 0.001 \\
\hline AR(2), p-value & 0.278 & 0.342 & 0.398 & 0.285 & 0.320 & 0.378 \\
\hline Hansen, p-value & 0.044 & 0.017 & 0.017 & 0.208 & 0.141 & 0.162 \\
\hline Number of intruments & 40 & 42 & 42 & 45 & 47 & 47 \\
\hline Number of states & 47 & 47 & 47 & 47 & 47 & 47 \\
\hline Number of observations & 1,551 & 1,551 & 1,551 & 1,551 & 1,551 & 1,551 \\
\hline
\end{tabular}

\section{Dependent variable: Primary surplus 2-to-GDP ratio (excluding fiscal transfers)}

Note: Two-step system GMM with robust standard errors in parantheses; instruments collapsed and limited to the $5^{\text {th }}$ lag; ***, ** and * denote significance at the $1 \%, 5 \%$ and $10 \%$ levels;

The panel is balanced with samples for 47 US states (Alaska, Hawaii, Wyoming excluded) covering the period 1978-2010. 
Table 5: Fiscal reaction functions including fiscal transfers in the West German states

\begin{tabular}{|c|c|c|c|c|c|c|}
\hline Variables & (1) & $(2)$ & (3) & (4) & (5) & (6) \\
\hline Lagged debt-to-GDP ratio & $\begin{array}{c}0.079 * * * \\
(0.016)\end{array}$ & $\begin{array}{c}0.072 * * * \\
(0.014)\end{array}$ & $\begin{array}{c}0.072 * * * \\
(0.013)\end{array}$ & $\begin{array}{c}0.040^{* * *} \\
(0.011)\end{array}$ & $\begin{array}{c}0.034 * * \\
(0.011)\end{array}$ & $\begin{array}{c}0.035^{* * *} \\
(0.010)\end{array}$ \\
\hline YVAR & & $\begin{array}{c}0.330 \\
(0.187)\end{array}$ & & & $\begin{array}{l}-0.313 \\
(0.208)\end{array}$ & \\
\hline GVAR & & $\begin{array}{c}-0.636^{* * *} \\
(0.147)\end{array}$ & & & $\begin{array}{c}-0.702^{* * *} \\
(0.072)\end{array}$ & \\
\hline Output gap & & & $\begin{array}{c}-0.055 \\
(0.034)\end{array}$ & & & $\begin{array}{c}0.027 \\
(0.027)\end{array}$ \\
\hline Expenditure gap & & & $\begin{array}{c}-0.649 * * * \\
(0.143)\end{array}$ & & & $\begin{array}{c}-0.675^{* * *} \\
(0.063)\end{array}$ \\
\hline Lagged dependent variable & & & & $\begin{array}{c}0.677 * * * \\
(0.028)\end{array}$ & $\begin{array}{c}0.685^{* * *} \\
(0.032)\end{array}$ & $\begin{array}{c}0.679 * * * \\
(0.029)\end{array}$ \\
\hline Fixed time effects & Yes & Yes & Yes & Yes & Yes & Yes \\
\hline Fixed state effects & Yes & Yes & Yes & Yes & Yes & Yes \\
\hline R-squared (overall) & 0.233 & 0.291 & 0.293 & 0.621 & 0.692 & 0.689 \\
\hline Number of states & 10 & 10 & 10 & 10 & 10 & 10 \\
\hline Number of observations & 360 & 360 & 360 & 360 & 360 & 360 \\
\hline
\end{tabular}

Dependent variable: Primary surplus 1-to-GDP ratio (standard measure)

Note: OLS with standard errors robust to heteroskedasticity (Huber/White/sandwich standard errors) in parentheses;

$* * *, * *$ and $*$ denote significance at the $1 \%, 5 \%$ and $10 \%$ levels;

The panel is balanced with samples for the 10 West German states covering the period 1975-2010. 
Table 6: Fiscal reaction functions excluding fiscal transfers in the West German states

\begin{tabular}{|c|c|c|c|c|c|c|}
\hline Variables & (1) & $(2)$ & (3) & (4) & (5) & (6) \\
\hline Lagged debt-to-GDP ratio & $\begin{array}{l}-0.007 \\
(0.014)\end{array}$ & $\begin{array}{l}-0.016 \\
(0.014)\end{array}$ & $\begin{array}{l}-0.016 \\
(0.013)\end{array}$ & $\begin{array}{c}0.003 \\
(0.008)\end{array}$ & $\begin{array}{l}-0.005 \\
(0.008)\end{array}$ & $\begin{array}{l}-0.005 \\
(0.008)\end{array}$ \\
\hline YVAR & & $\begin{array}{c}-0.516^{*} \\
(0.248)\end{array}$ & & & $\begin{array}{c}-0.636 * * \\
(0.225)\end{array}$ & \\
\hline GVAR & & $\begin{array}{c}-0.998 * * * \\
(0.111)\end{array}$ & & & $\begin{array}{c}-0.821^{* * * *} \\
(0.076)\end{array}$ & \\
\hline Output gap & & & $\begin{array}{c}0.052 \\
(0.040)\end{array}$ & & & $\begin{array}{l}0.071^{*} \\
(0.033)\end{array}$ \\
\hline Expenditure gap & & & $\begin{array}{c}-0.955^{* * * *} \\
(0.079)\end{array}$ & & & $\begin{array}{c}-0.773 * * * \\
(0.052)\end{array}$ \\
\hline Lagged dependent variable & & & & $\begin{array}{c}0.634 * * * \\
(0.043)\end{array}$ & $\begin{array}{c}0.583 * * * \\
(0.050)\end{array}$ & $\begin{array}{c}0.581 * * * \\
(0.049)\end{array}$ \\
\hline Fixed time effects & Yes & Yes & Yes & Yes & Yes & Yes \\
\hline Fixed state effects & Yes & Yes & Yes & Yes & Yes & Yes \\
\hline R-squared (overall) & 0.194 & 0.323 & 0.321 & 0.866 & 0.885 & 0.883 \\
\hline Number of states & 10 & 10 & 10 & 10 & 10 & 10 \\
\hline Number of observations & 360 & 360 & 360 & 360 & 360 & 360 \\
\hline
\end{tabular}

Dependent variable: Primary surplus 2-to-GDP ratio (excluding fiscal transfers)

Note: OLS with standard errors robust to heteroskedasticity (Huber/White/sandwich standard errors) in parentheses;

$* * *, * *$ and $*$ denote significance at the $1 \%, 5 \%$ and $10 \%$ levels;

The panel is balanced with samples for the 10 West German states covering the period 1975-2010. 
Table 7: Debt and transfers in the US states (explanatory variables of the fiscal reaction function)

\begin{tabular}{|c|c|c|c|c|c|c|}
\hline Variables & (1) & (2) & (3) & (4) & (5) & (6) \\
\hline Lagged. debt-to-GDP ratio & $\begin{array}{c}0.041^{* *} \\
(0.020)\end{array}$ & $\begin{array}{c}0.032 \\
(0.019)\end{array}$ & $\begin{array}{c}0.031 \\
(0.020)\end{array}$ & $\begin{array}{c}0.006 * * \\
(0.003)\end{array}$ & $\begin{array}{c}0.003 \\
(0.003)\end{array}$ & $\begin{array}{c}0.003 \\
(0.003)\end{array}$ \\
\hline YVAR & & $\begin{array}{c}0.470 * * * \\
(0.076)\end{array}$ & & & $\begin{array}{c}0.230 * * * \\
(0.041)\end{array}$ & \\
\hline GVAR & & $\begin{array}{c}0.281^{* * *} \\
(0.040)\end{array}$ & & & $\begin{array}{c}0.190 * * * \\
(0.023)\end{array}$ & \\
\hline Output gap & & & $\begin{array}{c}-0.046 * * * \\
(0.007)\end{array}$ & & & $\begin{array}{c}-0.021 * * * \\
(0.004)\end{array}$ \\
\hline Expenditure gap & & & $\begin{array}{c}0.270 * * * \\
(0.041)\end{array}$ & & & $\begin{array}{c}0.183^{* * *} \\
(0.024)\end{array}$ \\
\hline Lagged dependent variable & & & & $\begin{array}{c}0.895 * * * \\
(0.019)\end{array}$ & $\begin{array}{c}0.872 * * * \\
(0.026)\end{array}$ & $\begin{array}{c}0.873 * * * \\
(0.026)\end{array}$ \\
\hline Fixed time effects & Yes & Yes & Yes & Yes & Yes & Yes \\
\hline Fixed state effects & Yes & Yes & Yes & Yes & Yes & Yes \\
\hline R-squared (overall) & 0.293 & 0.298 & 0.297 & 0.956 & 0.959 & 0.958 \\
\hline Number of states & 47 & 47 & 47 & 47 & 47 & 47 \\
\hline Number of observations & 1,551 & 1,551 & 1,551 & 1,551 & 1,551 & 1,551 \\
\hline
\end{tabular}

Dependent variable: Net transfers-to-GDP ratio

Note: OLS with standard errors robust to heteroskedasticity (Huber/White/sandwich standard errors) in parentheses;

$* * *, * *$ and $*$ denote significance at the $1 \%, 5 \%$ and $10 \%$ levels;

The panel is balanced with samples for 47 US states (Alaska, Hawaii, Wyoming excluded) covering the period 1978-2010. 
Table 8: Debt and transfers in the West German states (explanatory variables of the fiscal reaction function)

\begin{tabular}{|c|c|c|c|c|c|c|}
\hline Variables & (1) & $(2)$ & (3) & (4) & (5) & (6) \\
\hline Lagged debt-to-GDP ratio & $\begin{array}{c}0.086^{* * *} \\
(0.017)\end{array}$ & $\begin{array}{c}0.087 * * * \\
(0.018)\end{array}$ & $\begin{array}{c}0.087 * * * \\
(0.018)\end{array}$ & $\begin{array}{c}0.022^{* *} \\
(0.008)\end{array}$ & $\begin{array}{c}0.021^{* *} \\
(0.008)\end{array}$ & $\begin{array}{c}0.020^{* *} \\
(0.008)\end{array}$ \\
\hline YVAR & & $\begin{array}{c}0.856 * * * \\
(0.245)\end{array}$ & & & $\begin{array}{l}0.177^{*} \\
(0.085)\end{array}$ & \\
\hline GVAR & & $\begin{array}{c}0.316 \\
(0.242)\end{array}$ & & & $\begin{array}{l}-0.079 * \\
(0.039)\end{array}$ & \\
\hline Output gap & & & $\begin{array}{c}-0.108 * * \\
(0.045)\end{array}$ & & & $\begin{array}{c}-0.028 * \\
(0.013)\end{array}$ \\
\hline Expenditure gap & & & $\begin{array}{c}0.259 \\
(0.198)\end{array}$ & & & $\begin{array}{l}-0.087 * \\
(0.040)\end{array}$ \\
\hline Lagged dependent variable & & & & $\begin{array}{c}0.885^{* * *} \\
(0.015)\end{array}$ & $\begin{array}{c}0.885^{* * *} \\
(0.019)\end{array}$ & $\begin{array}{c}0.886 * * * \\
(0.019)\end{array}$ \\
\hline Fixed time effects & Yes & Yes & Yes & Yes & Yes & Yes \\
\hline Fixed state effects & Yes & Yes & Yes & Yes & Yes & Yes \\
\hline R-squared (overall) & 0.584 & 0.591 & 0.589 & 0.956 & 0.957 & 0.957 \\
\hline Number of states & 10 & 10 & 10 & 10 & 10 & 10 \\
\hline Number of observations & 360 & 360 & 360 & 360 & 360 & 360 \\
\hline
\end{tabular}

Dependent variable: Net transfers-to-GDP ratio

Note: OLS with standard errors robust to heteroskedasticity (Huber/White/sandwich standard errors) in parentheses;

$* * *, * *$ and $*$ denote significance at the $1 \%, 5 \%$ and $10 \%$ levels;

The panel is balanced with samples for the 10 West German states covering the period 1975-2010. 
Table 9: Debt and transfers in the US states

\begin{tabular}{|c|c|c|c|c|}
\hline \multirow[b]{2}{*}{ Variables } & \multicolumn{2}{|c|}{ "Levels } & \multicolumn{2}{|c|}{ 5-year averages } \\
\hline & (1) & (2) & (3) & (4) \\
\hline Lagged debt-to-GDP ratio & $\begin{array}{c}0.037 * * \\
(0.016)\end{array}$ & $\begin{array}{c}0.008 * * * \\
(0.003)\end{array}$ & $\begin{array}{l}0.035^{*} \\
(0.019)\end{array}$ & $\begin{array}{c}0.012 \\
(0.018)\end{array}$ \\
\hline Lagged population & $\begin{array}{l}-0.004 \\
(0.003)\end{array}$ & $\begin{array}{l}-0.001 * \\
(0.001)\end{array}$ & $\begin{array}{l}-0.004 \\
(0.003)\end{array}$ & $\begin{array}{l}-0.002 \\
(0.002)\end{array}$ \\
\hline Lagged population share 5-17 & $\begin{array}{l}-0.118^{*} \\
(0.064)\end{array}$ & $\begin{array}{c}-0.030 * * \\
(0.014)\end{array}$ & $\begin{array}{c}-0.178 * * \\
(0.076)\end{array}$ & $\begin{array}{c}-0.092^{* *} \\
(0.040)\end{array}$ \\
\hline Lagged population share $>65$ & $\begin{array}{c}0.150 \\
(0.107)\end{array}$ & $\begin{array}{c}0.002 \\
(0.024)\end{array}$ & $\begin{array}{c}0.053 \\
(0.143)\end{array}$ & $\begin{array}{l}-0.149 \\
(0.109)\end{array}$ \\
\hline Lagged per capita personal income & $\begin{array}{c}-0.008 * * * \\
(0.003)\end{array}$ & $\begin{array}{l}-0.001 * \\
(0.001)\end{array}$ & $\begin{array}{l}-0.005 \\
(0.004)\end{array}$ & $\begin{array}{l}-0.001 \\
(0.003)\end{array}$ \\
\hline Lagged unemployment rate & $\begin{array}{c}0.014 \\
(0.020)\end{array}$ & $\begin{array}{l}0.011^{*} \\
(0.006)\end{array}$ & $\begin{array}{l}-0.042 \\
(0.034)\end{array}$ & $\begin{array}{l}-0.046 \\
(0.029)\end{array}$ \\
\hline Lagged Senators per capita & $\begin{array}{c}0.010 * * * \\
(0.002)\end{array}$ & $\begin{array}{c}0.001 \\
(0.001)\end{array}$ & $\begin{array}{c}0.003 \\
(0.004)\end{array}$ & $\begin{array}{l}-0.005 \\
(0.004)\end{array}$ \\
\hline Lagged dependent variable & & $\begin{array}{c}0.872 * * * \\
(0.025)\end{array}$ & & $\begin{array}{c}0.744^{* * *} \\
(0.161)\end{array}$ \\
\hline Fixed time effects & Yes & Yes & Yes & Yes \\
\hline Fixed state effects & Yes & Yes & Yes & Yes \\
\hline R-squared (overall) & 0.428 & 0.953 & 0.353 & 0.598 \\
\hline $\begin{array}{l}\text { Number of states } \\
\text { Number of observations }\end{array}$ & $\begin{array}{c}47 \\
1,551\end{array}$ & $\begin{array}{c}47 \\
1,551\end{array}$ & $\begin{array}{c}47 \\
235\end{array}$ & $\begin{array}{c}47 \\
235\end{array}$ \\
\hline
\end{tabular}

Dependent variable: Net transfers-to-GDP ratio

Note: OLS with standard errors robust to heteroskedasticity (Huber/White/sandwich standard errors) in parentheses;

***, ** and * denote significance at the $1 \%, 5 \%$ and $10 \%$ levels;

The panel is balanced with samples for 47 US states (Alaska, Hawaii, Wyoming excluded) covering the period 1978-2010. 
Table 10: Debt and transfers in the West German states

\begin{tabular}{|c|c|c|c|c|}
\hline \multirow[b]{2}{*}{ Variables } & \multicolumn{2}{|c|}{ Levels } & \multicolumn{2}{|c|}{ 5-year averages } \\
\hline & (1) & (2) & (3) & (4) \\
\hline Lagged debt-to-GDP ratio & $\begin{array}{c}0.039 * * \\
(0.015)\end{array}$ & $\begin{array}{c}0.031^{* *} \\
(0.010)\end{array}$ & $\begin{array}{c}0.044 \\
(0.028)\end{array}$ & $\begin{array}{c}0.014 \\
(0.032)\end{array}$ \\
\hline Lagged tax power & $\begin{array}{c}-0.047 * * * \\
(0.009)\end{array}$ & $\begin{array}{l}-0.002 \\
(0.012)\end{array}$ & $\begin{array}{c}-0.044 * * \\
(0.017)\end{array}$ & $\begin{array}{c}0.003 \\
(0.025)\end{array}$ \\
\hline Dummy 1994-2004 (Saarland, Bremen) & $\begin{array}{c}0.032 * * * \\
(0.005)\end{array}$ & $\begin{array}{c}0.011^{* * *} \\
(0.001)\end{array}$ & $\begin{array}{c}0.022^{* * *} \\
(0.004)\end{array}$ & $\begin{array}{c}0.025^{* * *} \\
(0.002)\end{array}$ \\
\hline Lagged dependent variable & & $\begin{array}{c}0.662 * * * \\
(0.059)\end{array}$ & & $\begin{array}{c}0.450 * * * \\
(0.059)\end{array}$ \\
\hline Fixed time effects & Yes & Yes & Yes & Yes \\
\hline Fixed state effects & Yes & Yes & Yes & Yes \\
\hline R-squared (overall) & 0.915 & 0.957 & 0.886 & 0.933 \\
\hline Number of states & 10 & 10 & 10 & 10 \\
\hline Number of observations & 360 & 360 & 60 & 60 \\
\hline
\end{tabular}

\section{Dependent variable: Net transfers-to-GDP ratio}

Note: OLS with standard errors robust to heteroskedasticity (Huber/White/sandwich standard errors) in parentheses;

$* * *, * *$ and $*$ denote significance at the $1 \%, 5 \%$ and $10 \%$ levels;

The panel is balanced with samples for the 10 West German states covering the period 1975-2010. 
Figure 1a: Primary surplus 1 and 2 in the US states (1/2)

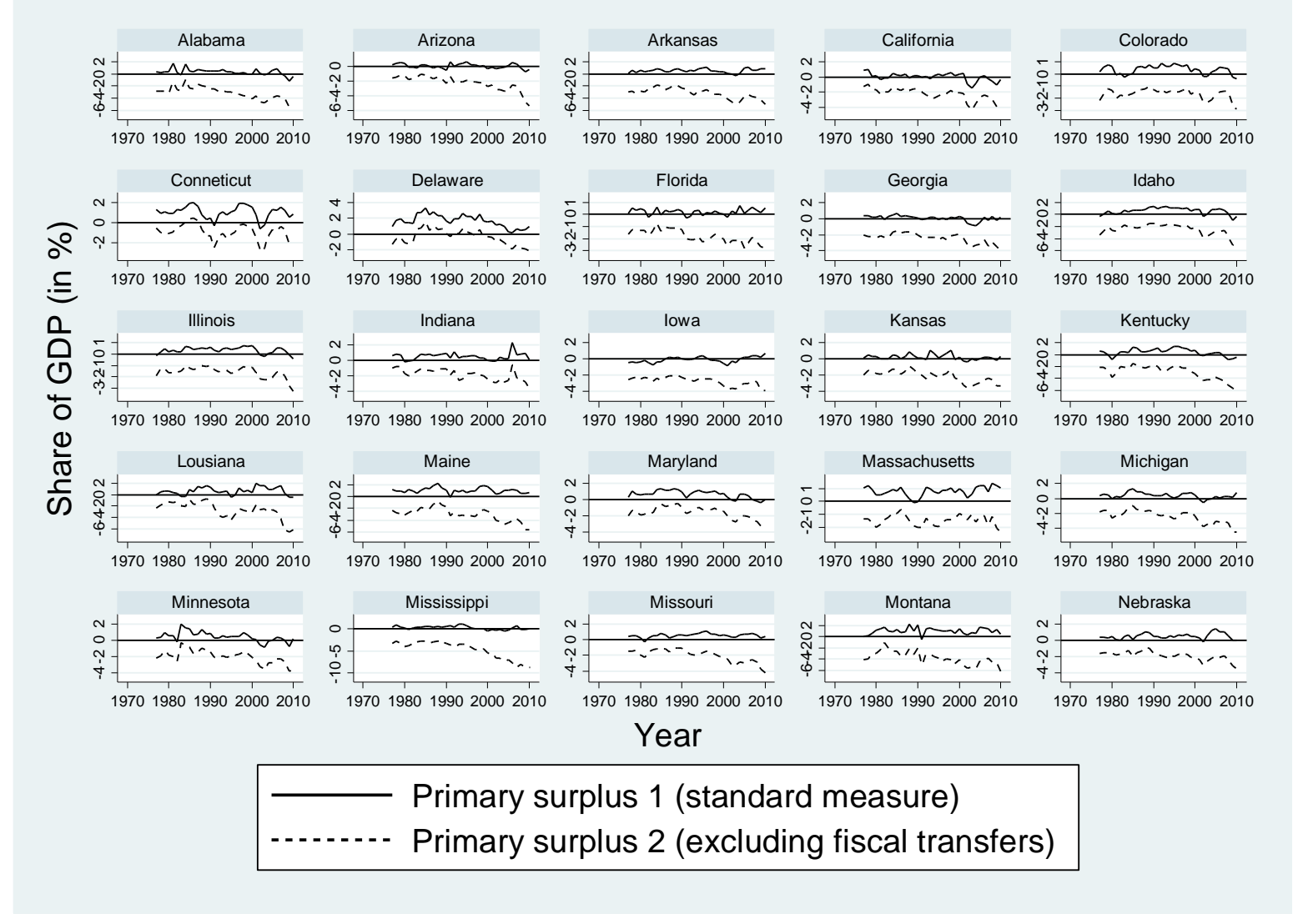

Note: Primary surplus 1 denotes the standard measure of the primary surplus, primary surplus 2 denotes the primary surplus excluding fiscal transfers. 


\section{Figure 1a: Primary surplus 1 and 2 in the US states (2/2)}

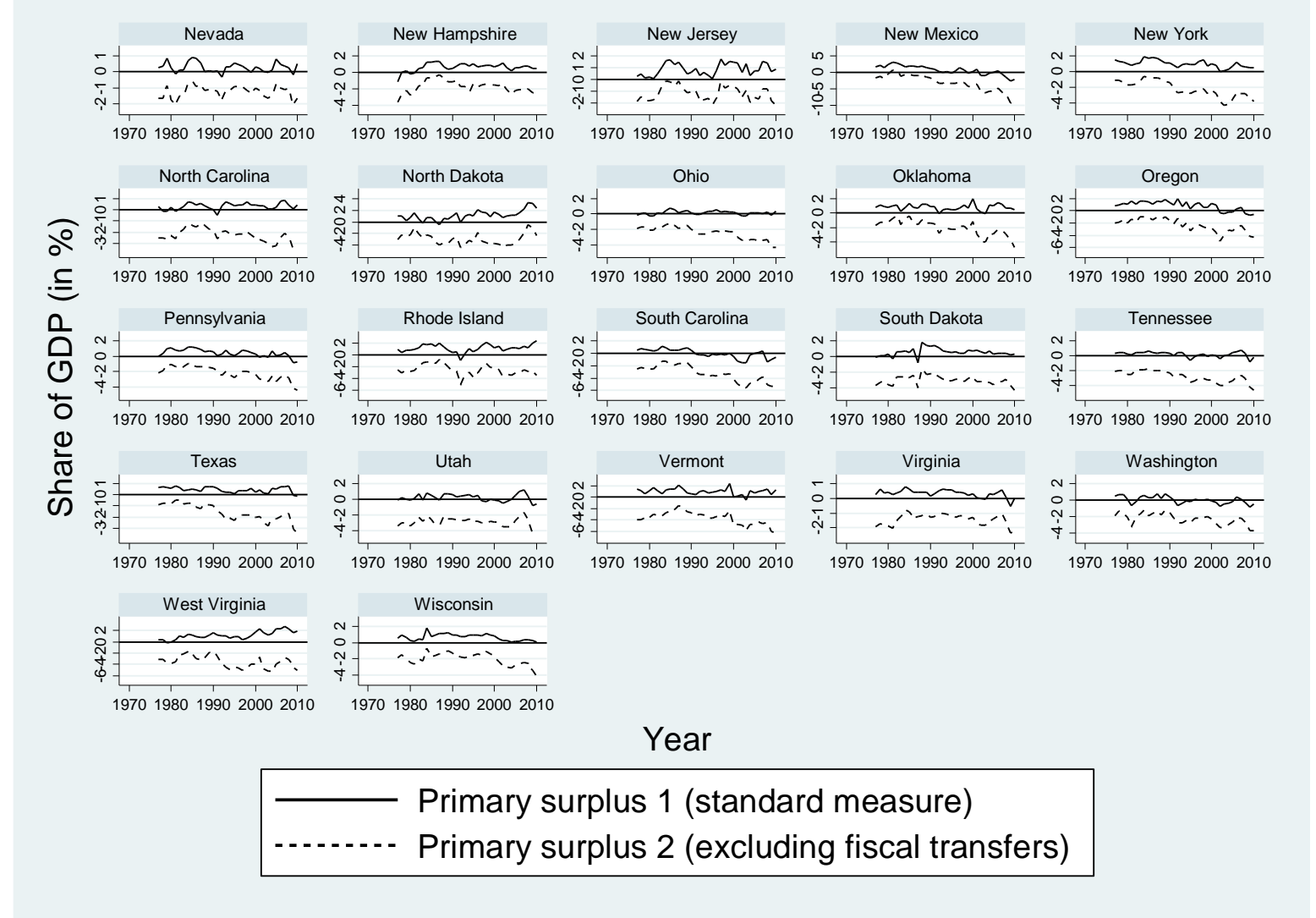

Note: Primary surplus 1 denotes the standard measure of the primary surplus, primary surplus 2 denotes the primary surplus excluding fiscal transfers. 


\section{Figure 1b: Primary surplus 1 and 2 in the West German states}

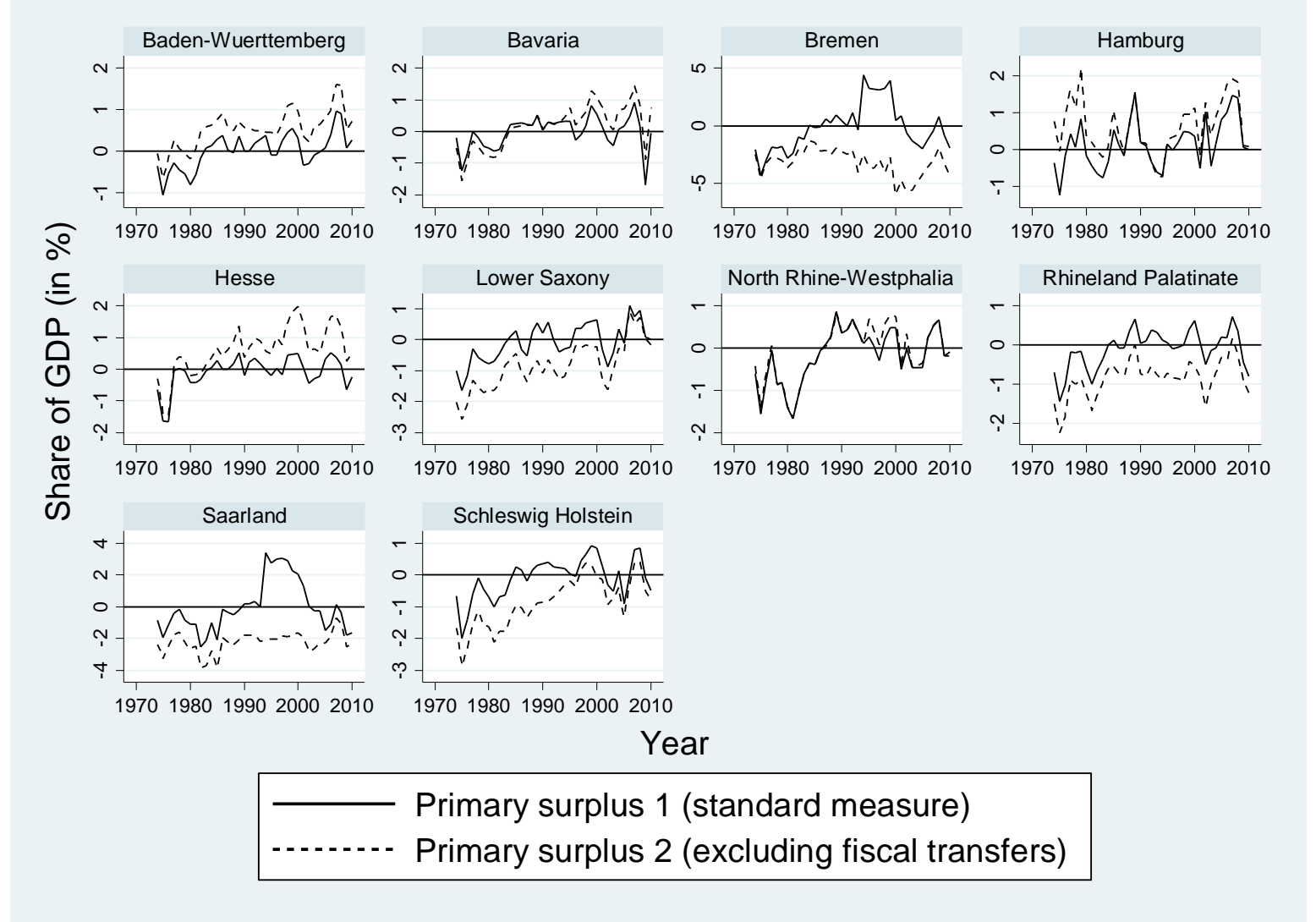

Note: Primary surplus 1 denotes the standard measure of the primary surplus, primary surplus 2 denotes the primary surplus excluding fiscal transfers. 


\section{Figure 2a: Debt and primary surplus in the US states}

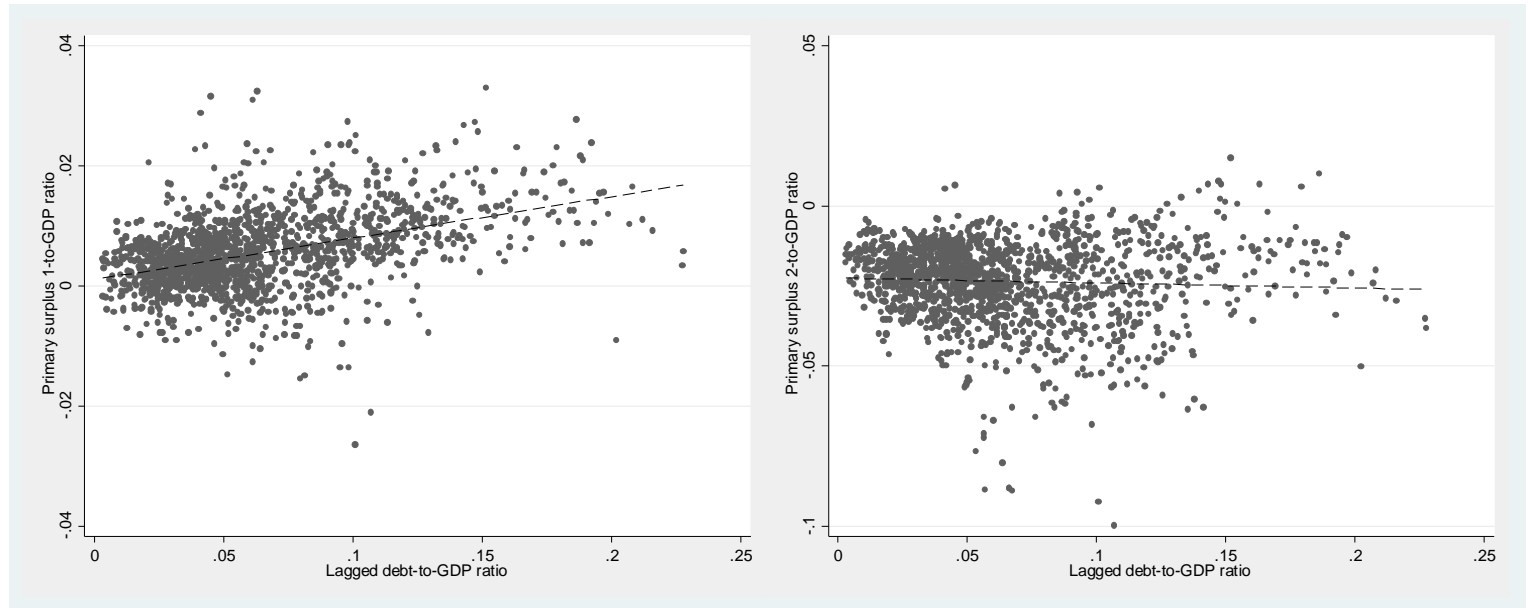

Note: Left panel: Primary surplus 1-to-GDP ratio and lagged debt-to-GDP ratio; Right panel: Primary surplus 2-to-GDP ratio and lagged debt-to-GDP ratio. Annual data for 47 US states (Alaska, Hawaii, Wyoming excluded) over the period 1978-2010.

Correlation coefficient between lagged debt-to-GDP-ratio and primary surplus 1-to-GDP ratio (standard measure): 0.42

Correlation coefficient between lagged debt-to-GDP-ratio and primary surplus 2-to-GDP ratio (fiscal transfers excluded): -0.05 


\section{Figure 2b: Debt and primary surplus in the West German states}

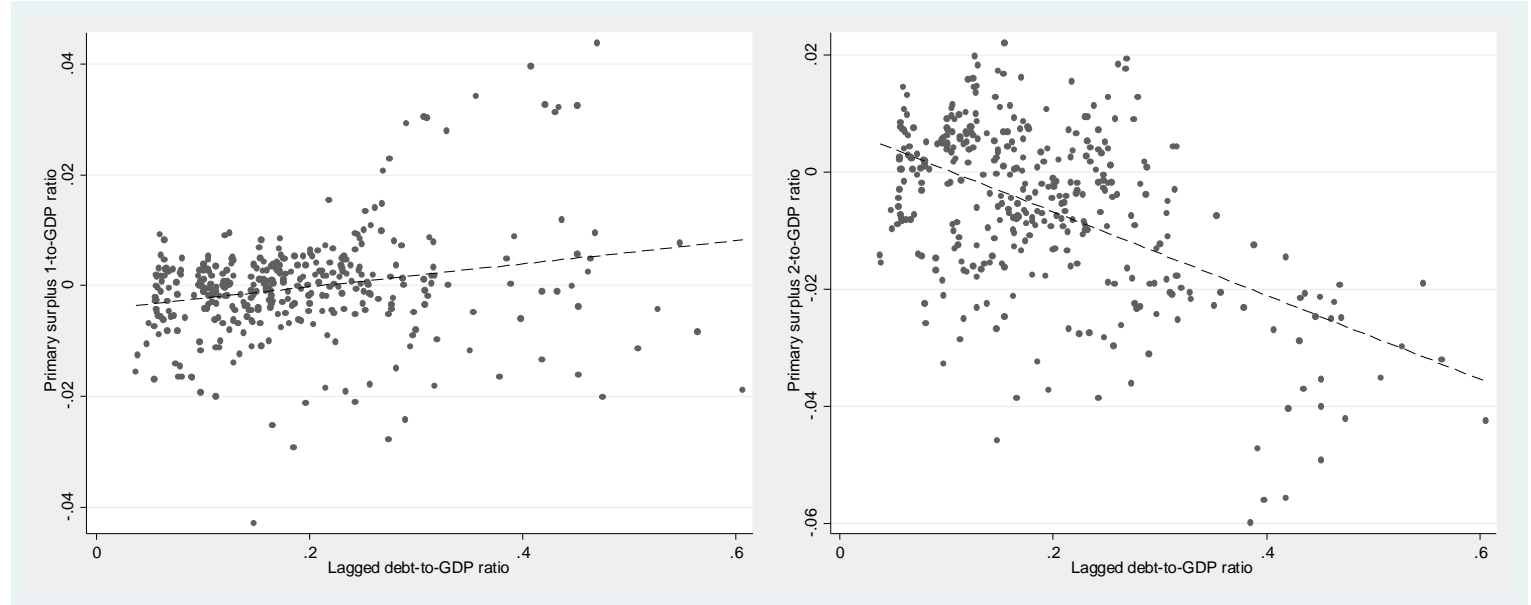

Note: Left panel: Primary surplus 1-to-GDP ratio and lagged debt-to-GDP ratio; Right panel: Primary surplus 2-to-GDP ratio and lagged debt-to-GDP ratio. Annual data for 10 West German states over the period 1975-2010 (debt over the period 1974-2009).

Correlation coefficient betwee lagged debt-to-GDP-ratio and primary surplus 1-to-GDP ratio (standard measure): 0.23

Correlation coefficient between lagged debt-to-GDP-ratio and primary surplus 2-to-GDP ratio (fiscal transfers excluded): -0.53 
Figure 3a: Debt and transfers in the US states

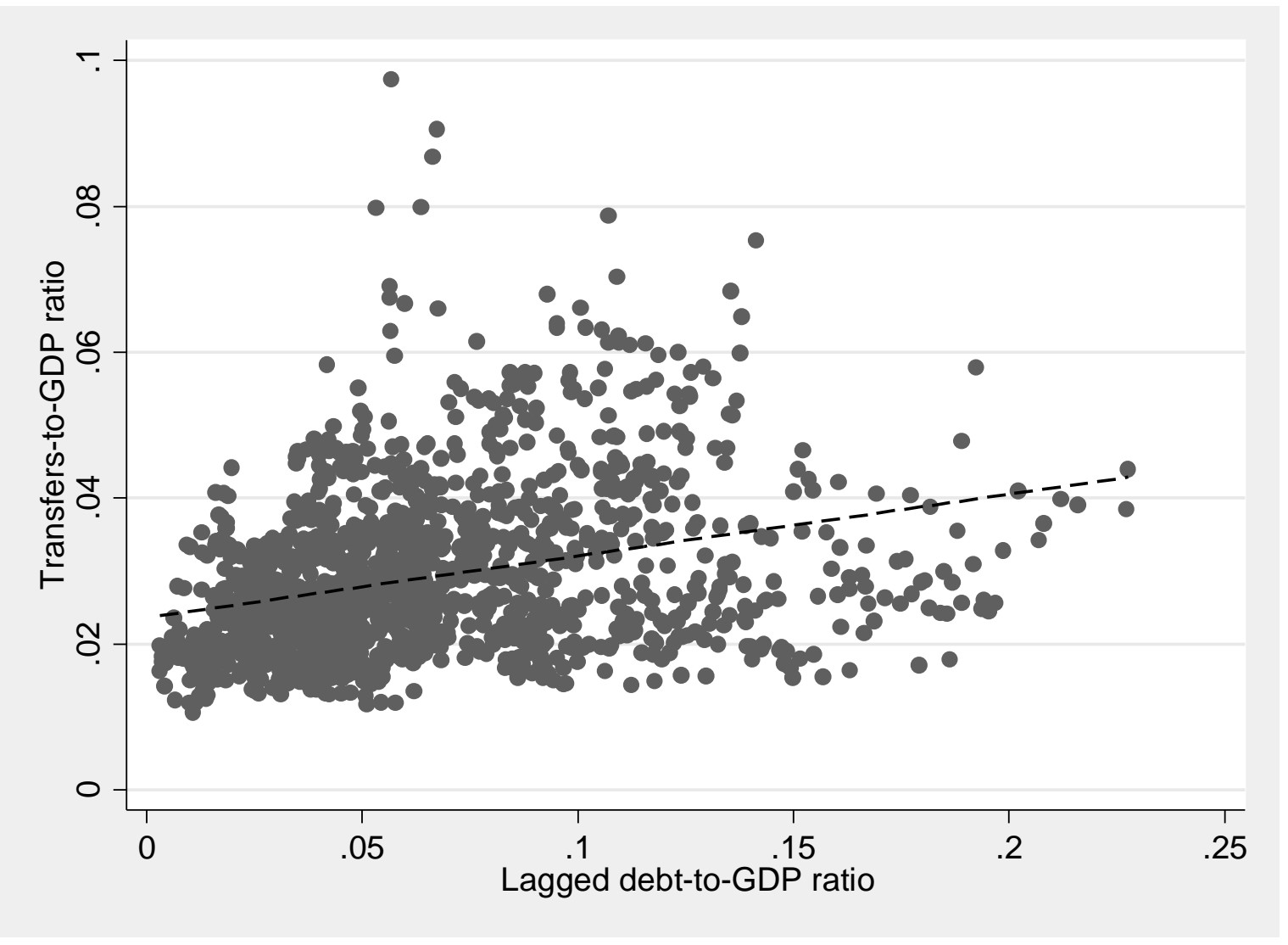

Note: Annual data for 47 US states (Alaska, Hawaii, Wyoming excluded) over the period 1978-2010.

Correlation coefficient between lagged debt-to-GDP ratio and transfers-to-GDP ratio: 0.30 
Figure 3b: Debt and transfers in the West German states

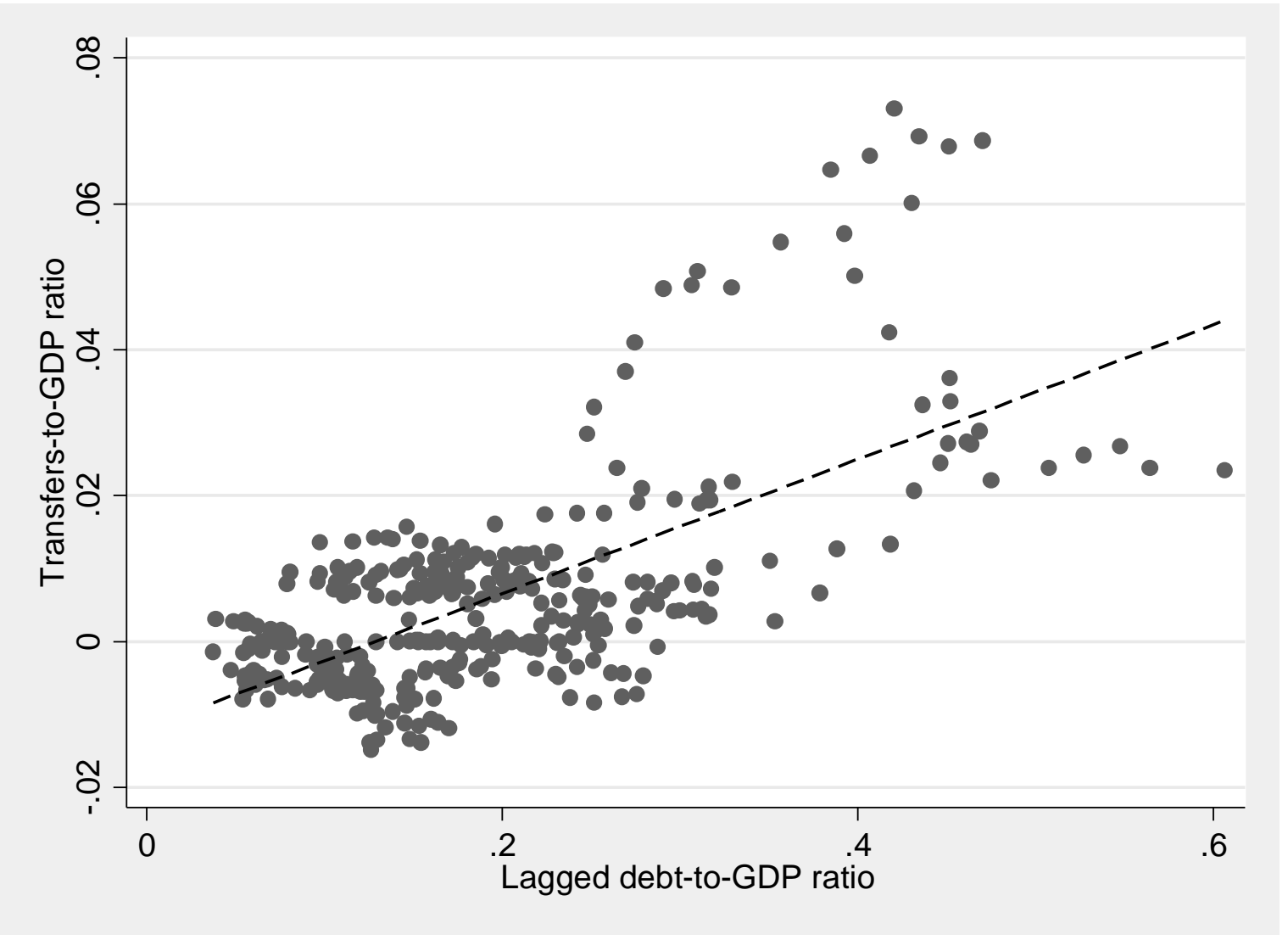

Note: Annual data for 10 West German states over the period 1975-2010.

Correlation coefficient between lagged debt-to-GDP ratio and transfers-to-GDP ratio: 0.67 